\title{
PALEOECOLOGICAL PATTERNS AT THE COAL-ROOF SHALE TRANSITION IN AN OUTCROP OF THE PERMIAN BRAZILIAN GONDWANA
}

\author{
MARGOT GUERRA-SOMMER, MIRIAM CAZZULO-KLEPZIG \\ Instituto de Geociências, UFRGS, Cx.P. 15001, 91501-970, Porto Alegre, RS, Brazil.margot.sommer@ufrgs.br
}

\begin{abstract}
ANDRÉ JASPER
Setor de Botânica e Paleobotânica, Museu de Ciências Naturais, Centro Universitário UNIVATES, Rua Avelino Tallini, 171, 95900-000, Lajeado, RS, Brazil.
\end{abstract}

\author{
WOLFGANG KALKREUTH, RUALDO MENEGAT \& EDUARDO G. BARBOZA \\ Instituto de Geociências, UFRGS, Cx.P. 15001, 91501-970, Porto Alegre, RS, Brazil.
}

\begin{abstract}
The paleoecology of the depositional interval at the transition from a peat-forming to a clastic environment in an outcrop of the Rio Bonito Formation (Sakmarian) of the southern Paraná Basin (Rio Grande do Sul State, Brazil) is outlined here. The autochtonous roof shale flora is dominated by a homogeneous assemblage of in situ arborescent lycopsid casts (Brasilodendron pedroanum), associated with understorey forms (Botrychiopsis valida, Lycopodites sp., rhodeopterid forms) and hypoauthochtonous conifers (Coricladus quiteriensis), as well as leaves of Rubidgea and Cordaites, transported from nearby lowland areas. Palynological observations in the underlying coal bed combined with studies of the roof shale indicate that the roof shale plant assemblage reflects partly the plants that grew in peat-forming swamps which originated the hypoauthochtonous coal. Quantitative and qualitative differences between peat-forming and clastic paleofloras are linked to changes in paleosoil characteristics. Episodic flooding by washover fans was the dominant controlling process in the evolution of facies in the vegetated coastal area, over a relatively short time scale. High levels of structured fusinite and inertodetrinite, shown by petrographic analysis in carbonaceous shales, as well as the presence of charcoal in the clastic entisoil, reflect frequent fires disturbing nearby lowland areas. Paleoecological characteristics of the megaflora indicate wetdry oscillations during the depositional interval, which should be related to climatic seasonality. A framework is proposed for the development of peat and subsequent process of colonization, succession and burial of a clastic plant-community preserved as roof shale flora.
\end{abstract}

Key words: Coal-roof shale transition, paleoecology, Early Permian, Gondwana, wildfires.

RESUMO - São delineados cenários para o intervalo deposicional correspondente à transição de um leito de carvão, para níveis de roof shale, em afloramento da Formação Rio Bonito (Sakmariano), sul da bacia do Paraná. A flora autóctone identificada no roof shale é dominada por moldes de licófitas arborescentes preservados in situ (Brasilodendron), formas desenvolvidas sob o dossel (Botrychiopsis valida, Lycopodites sp., frondes rodopterídeas), coníferas (Coricladus quiteriensis) e folhas de Rubidgea e Cordaites transportadas de áreas marginais baixas. A comparação entre dados palinológicos obtidos nos níveis carbonosos subjacentes e informações paleobotânicas vindas do roof shale, evidencia similaridade composicional. Afogamentos episódicos de pequena escala, causados por leques de washover, controlaram o processo de evolução de fácies nas áreas costeiras. Altos níveis de fusinita estruturada e inertodetrinita, evidenciados por estudos petrográficos nos carvões e folhelhos carbonosos, e a abundância de charcoal, relacionado principalmente a fragmentos de lenho, refletem a freqüência de incêndios como importante processo de perturbação na vegetação em áreas proximais baixas. Estas evidências, associadas ao caráter autóctone de formas desenvolvidas sob o dossel, parecem indicar oscilações de condições úmidas e secas, relacionadas com sazonalidade climática. Foi estabelecido um arcabouço para o processo de formação da turfeira geradora $\mathrm{e}$ a subseqüente colonização, sucessão e sepultamento da vegetação clástica preservada como flora de roof shale.

Palavras-chave: transição carvão-roof shale, paleoecologia, Permiano Inferior, Gondwana, incêndios florestais.

\section{INTRODUCTION}

In the Lower Permian coal-bearing strata of South Brazilian Gondwana, common adpression floras occur in beds, which have no direct or indirect relationships with coal beds. Most roof shales lack megafloral remains and others are considered to be barren because concentrated megafloras are not present. However, in some coal successions well-preserved roof shale floras are present and are an important source of information concerning Early Permian Gondwana flora (e.g., Faxinal Coalfield described by Guerra-Sommer, 1988). The term "roof shale flora" refers to a plant-bearing bed just above a coal 
seam; these rocks can be siltstones or sandstones, though mudstones are the most common (Martín-Closas \& Gomez, 2004).

An exceptionally well-preserved roof shale flora was found in the Quiteria outcrop, a fragmented sedimentary exposure of the Rio Bonito Formation preserved as a faulted block, in Rio Grande do Sul State (Figure 1). The extraction of kaolinite in an open pit exposed a section interval of $6.40 \mathrm{~m}$ thick and $30 \mathrm{~m}$ wide on the northern slope of the outcropping area (Figure 2). Two sedimentary sections are evident: the basal light to dark grayish section is composed of conglomerates and thin coal layers, (1 to $10 \mathrm{~cm}$ thick, continuous) and associated with carbonaceous shales. The overlying clastic yellow-reddish color section is demarcated by an autochtonous assemblage of basal flared casts of arborescent lycophytes, characterized as a "roof shale flora." Multidisciplinary studies encompassing analyses of sedimentary facies based on sequence stratigraphy concepts, paleobotany and palynology (Jasper et al., 2006) have aimed at establishing the relationships between depositional cyclicity and changes in paleoecological patterns.

The present paper focuses specifically on the transition coal to roof shale in the Quitéria outcropping sequence with the purpose of: (i) establishing a framework to explain the

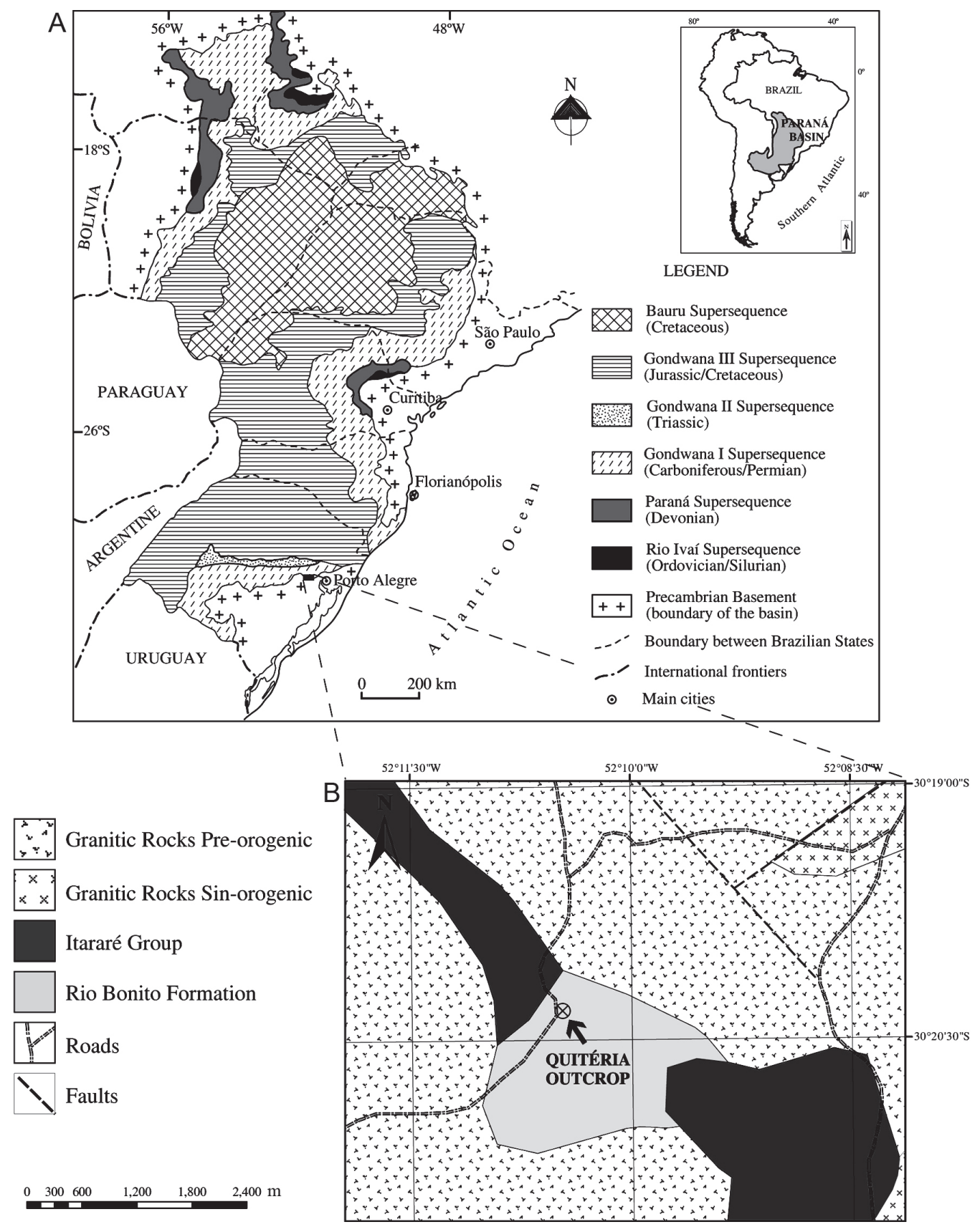

Figure 1. A, simplified geological map of the Paraná Basin in Brazil with major tectonic elements and geographic references (after Milani, 2003); B, location map of Quitéria area. 


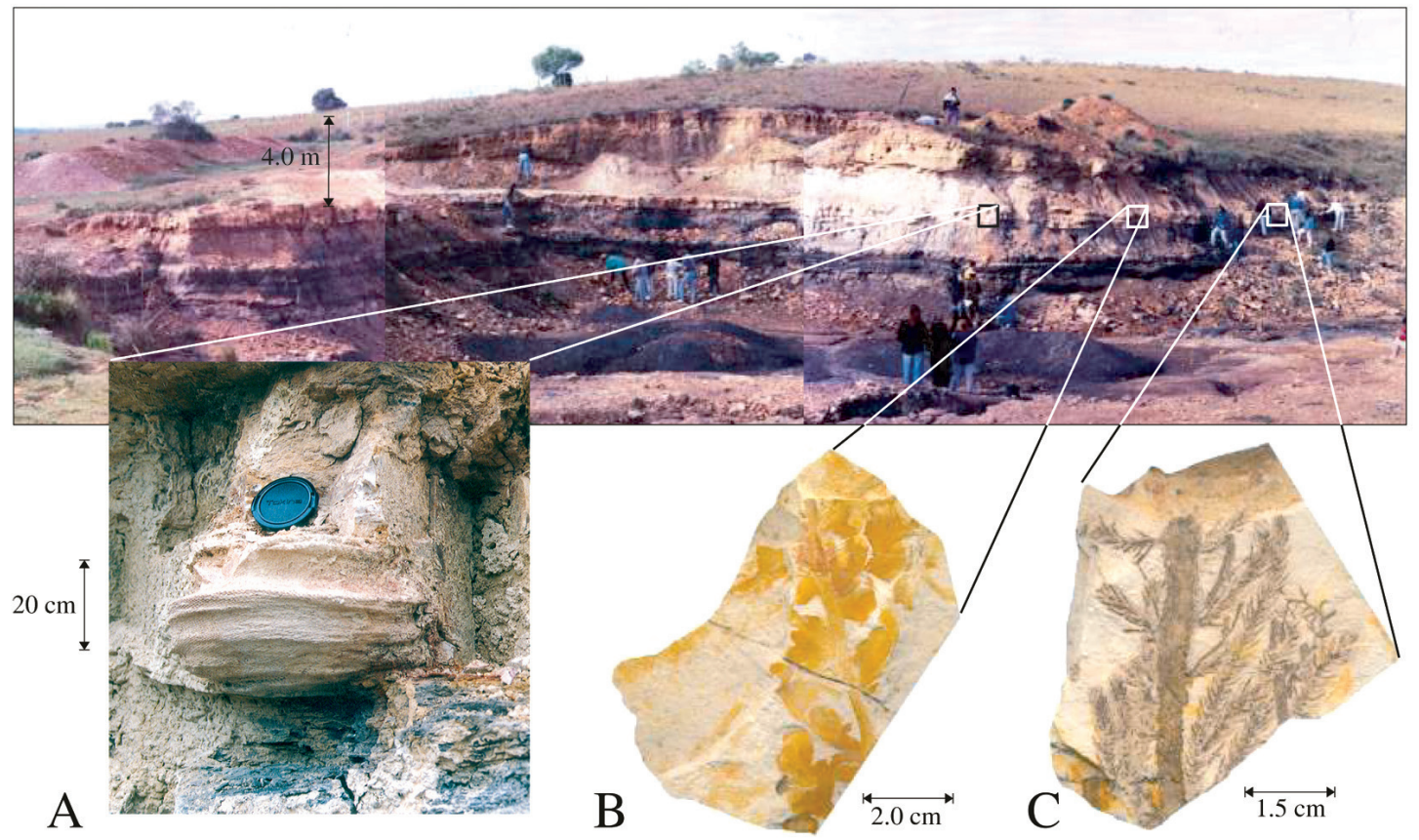

Figure 2. Quitéria outcrop (squares indicate the roof shale level): A, in situ basal lycophyte stem cast (Zone 1); B, Botrychiopsis valida frond; C, Coricladus quiteriensis shoot (Zone 2).

process of colonization, succession and burial of a clastic plant community preserved as a roof shale flora; (ii) clarifying the relationships between this clastic floristic assemblage with the underlying_coal_generating flora; (iii) outlining the paleoecological evolution which occurred during the depositional interval, linked to a coastal depositional system; (iv) investigating the influence of wildfires as important disturbance processes in the vegetation that grew in peatcoastal systems, the charcoal/inertodetrinite.

The present analyses were developed in a single case study and it is beyond the scope of this paper to discuss in detail large climatic controls; nevertheless, some of the factors that probably controlled dry-wet oscillations in the studied sequence discussed.

\section{MATERIAL AND METHODS}

\section{Depositional model and facies cyclicity patterns}

The depositional environment of roof shales and underlying coal sequence in the Quitéria Outcrop was identified by Jasper et al. (2006). The study was developed according to facies analysis in the conceptual framework by Walker \& James (1992), which postulates the subdivision of a sedimentary package into basic units, the facies. Criteria such as geometry, lithology, sedimentary structures, fossiliferous content and paleocurrent patterns were used to identify facies. Subsequently, the facies were grouped into nine vertical facies successions (FS), using criteria such as textural variation as well as kinds of contact surfaces. The facies succession allows the identification of depositional models. The present study focused on the upper FS V to FS VI interval (Figure 3).

\section{Megafloristic analyses}

Quadrat analysis was undertaken of compressed plant remains preserved on bedding surfaces associated with the upright basal stumps. Sampling of hypoauthochtonous specimens was carried out using a technique modified from Scott (1977) and Hughes (1986). Ecological analyses of percentage cover data are given by Simpson's diversity index. The distribution of the in situ basal lycophyte stems in different diameter classes was used to infer the maturity level of the arborescent forms.

The paleoecological reconstructions in the transition coalroof shale were also based on the taxonomic identification of different plant fragments which allowed the identification of the parent plants. Paleoecological and taphonomic data such as organic connection between fertile/sterile organs, stage of preservation and orientation were also used to reconstitute the vegetation patterns.

\section{Palynological analyses}

The recognition of plant communities in the coaly facies subjacent to the roof shale level was based on botanical affinities of spores and pollen grains and their preferential environment, following the concepts of Balme (1995). The palynological analyses developed by Jasper et al. (2006), followed the procedures outlined by Phipps \& Playford (1984) with minor modifications to achieve the best fraction. Palynological groups were considered abundant if they constituted more than $60 \%$ in the assemblage, frequent (between 30 and $60 \%$ ), less frequent ( 30 and $10 \%$ ) and scarce and rare (under 10\%). Paleoecological interpretation for the algae and algae-like elements (acritarchs) followed the criteria of Cazzulo-Klepzig et al. (2005) for coal palynofloras of the southernmost Paraná Basin in Brazil. 


\section{Coal petrography}

For petrographic analytical procedures in carbonaceous shales, blocks were made using epoxy for optical analyses, following standard procedures (Bustin et al., 1989). Petrographic composition was determined by analyzing the sample from the base to the top in $0.05-\mathrm{mm}$ increments. At each $0.05-\mathrm{mm}$ increment, a line parallel to the bedding of 20 $\mathrm{mm}$ length was analyzed in $1.0-\mathrm{mm}$ steps, thus giving a total of twenty points for each line, from which the percentage of maceral or mineral was calculated. Since a total of 22 lines were analyzed, the petrographic analysis was based on 400 points. The classification of organic matter followed the maceral concept of the ICCP $(1963,1998,2001)$.

All illustrated specimens are housed in the paleobotany collection, Museu de Ciências Naturais, Centro Universitário UNIVATES $(\mathrm{PbU})$ and in the Setor de Paleobotânica, Departamento de Paleontologia e Estratigrafia (Pb), UFRGS. Palynological slides are housed at the palynology collection (MP-P) of the Departamento de Paleontologia e Estratigrafia, Universidade Federal do Rio Grande do Sul .

\section{STRATIGRAPHIC FRAMEWORK OF COAL- BEARING}

The Paraná Basin is a large $\left(1,400,000 \mathrm{~km}^{2}\right)$ intracratonic sag basin covering part of southern Brazil, Paraguay,
Uruguay and Argentina. Basin floor subsidence, in addition to Palaeozoic sea-level changes, created six second-order sequences deposited from the Ordovician to Late Cretaceous, separated by regional unconformities (Figure 1A). The coalbearing Rio Bonito Formation, the object of this study, is part of two third-order depositional sequences of the Carboniferous-Early Triassic second-order sequence, named S2 and S3 (Holz et al., 2002).

Coal deposits of the Rio Bonito Formation occur in backbarrier environments adjacent to paralic (i.e., estuarine, deltaic), backshore, foreshore and shoreface siliciclastic deposits (Holz, 1998). Tissue preservation and gelification index corroborate deposition in a coastal swamp environment (Alves \& Ade, 1996). Deposition occurred in the cool temperate climatic belt (Scotese, 2000) or, according to the criteria of Rees et al. (1999), in the cool temperate bioma, at a paleolatitude of approximately $50^{\circ} \mathrm{S}$ (Scotese, 2000).

Geochronological schemes (Milani, 2003) proposed an Artinskian-Kungurian age for the coal deposition in the southern Paraná Basin, based mainly on palynostratigraphic data (Daemon \& Quadros, 1970; Marques-Toigo, 1991; Souza \& Marques-Toigo, 2003). However, correlation dificulties arise from the extension of the basin, the endemism of the Gondwana flora and the poor resolution of facies correlations in contiguous areas of the same basin. Hence, a new chronostratigraphic approach was needed.

Table 1. Facies and facies succession key (modified from Jasper et al., 2006). Svpc, very coarse sandstone with planar cross-bedding; Svtc, very coarse sandstone with through cross bedding; Sh, shale to coaly shale; Gmo, matrix-supported conglomerate; Sirm, Siltstone with root marks; Sil, siltstone with lamination; Si, Siltstone; Sm, medium sand; Sibr, Siltstone with B. pedroanum roots; Shc, coaly shale and coal; Gmco, coaly matrix-supported conglomerate; Sicrm, coaly siltstone with root marks; Gmc, coaly matrix-supported conglomerate with dispersed organic matter; Sic, coaly siltstone.

\begin{tabular}{|c|c|c|}
\hline $\begin{array}{l}\text { Facies } \\
\text { succession }\end{array}$ & Facies & Description \\
\hline FS IX & $\begin{array}{l}\text { Svpc } \\
\text { Svtc } \\
\text { Svpc }\end{array}$ & $\begin{array}{l}\text { Facies Svpc }(55 \mathrm{~cm} \text { thick }) \text { at the base, superimposed by Svtc }(30 \mathrm{~cm}) \text { followed by Svpc facies }(62 \\
\mathrm{cm}) \text {. }\end{array}$ \\
\hline FS VIII & $\begin{array}{c}\text { Sh } \\
\text { Gmo }\end{array}$ & $\begin{array}{l}\text { Fining upward succession of tabular beds. From base to top, facies are: Gmo (45 } \mathrm{cm} \text { thick), } \\
\text { superimposed by Sh }(15 \mathrm{~cm}) \text {; bounded with next succession by an erosional surface. }\end{array}$ \\
\hline FS VII & $\begin{array}{l}\text { Sirm } \\
\text { Sil } \\
\text { Sim } \\
\text { Sh }\end{array}$ & $\begin{array}{l}\text { Fining upward succession of tabular beds. From base to top, facies are: Sh }(12 \mathrm{~cm} \text { thick), Sim (15 } \\
\mathrm{cm}) \text {, Sil }(15 \mathrm{~cm}) \text {, and at the top, Sirm }(55 \mathrm{~cm}) \text {; bounded with next succession by an erosional } \\
\text { surface. }\end{array}$ \\
\hline FS VI & $\begin{array}{l}\text { Si } \\
\text { Sm } \\
\text { Sibr }\end{array}$ & $\begin{array}{l}\text { Fining upward succession of tabular beds. From base to top, facies are: Sibr ( } 4 \mathrm{~cm} \text { thick), Sm (37 } \\
\mathrm{cm}), \mathrm{Si}(4 \mathrm{~cm}) \text {, bounded with next succession by sharp surface. }\end{array}$ \\
\hline FS V & $\begin{array}{l}\text { Shc } \\
\text { Gmco }\end{array}$ & $\begin{array}{l}\text { Fining upward succession of tabular beds. From base to top, facies are: Gmco }(20 \mathrm{~cm} \text { thick), flat } \\
\text { contact with Shc }(20 \mathrm{~cm}) \text {, bounded with next succession by an erosional surface. }\end{array}$ \\
\hline FS IV & $\begin{array}{l}\text { Sicrm } \\
\text { Shc } \\
\text { Gmc }\end{array}$ & $\begin{array}{l}\text { Fining upward succession of tabular beds. From base to top, facies are: Gmc }(13 \mathrm{~cm} \text { thick), flat } \\
\text { contact with Shc }(20 \mathrm{~cm}) \text {, flat contact with Sicrm }(30 \mathrm{~cm}) \text {; bounded with next succession by an } \\
\text { erosional surface. }\end{array}$ \\
\hline FS III & $\begin{array}{l}\text { Shc } \\
\text { Gmc }\end{array}$ & $\begin{array}{l}\text { Fining upward succession of tabular beds. From base to top, facies are: } \mathrm{Gmc}(12 \mathrm{~cm} \text { thick), flat } \\
\text { contact with Shc }(8 \mathrm{~cm}) \text {; bounded with next succession by an erosional surface. }\end{array}$ \\
\hline FS II & $\begin{array}{l}\text { Shc } \\
\text { Gmc }\end{array}$ & $\begin{array}{l}\text { Fining upward succession of tabular beds. From base to top, facies are: } \mathrm{Gmc}(60 \mathrm{~cm} \text { thick), flat } \\
\text { contact with Shc }(15 \mathrm{~cm}) \text {; bounded with next succession by an erosional surface. }\end{array}$ \\
\hline FS I & $\begin{array}{l}\text { Shc } \\
\text { Sic }\end{array}$ & $\begin{array}{l}\text { Fining upward succession of tabular beds. From base to top, facies are: Sic (50 cm thick), flat } \\
\text { contact with Shc }(15 \mathrm{~cm}) \text {. The lowermost contact is covered and the contact with next succession is } \\
\text { erosional flat surface. }\end{array}$ \\
\hline
\end{tabular}




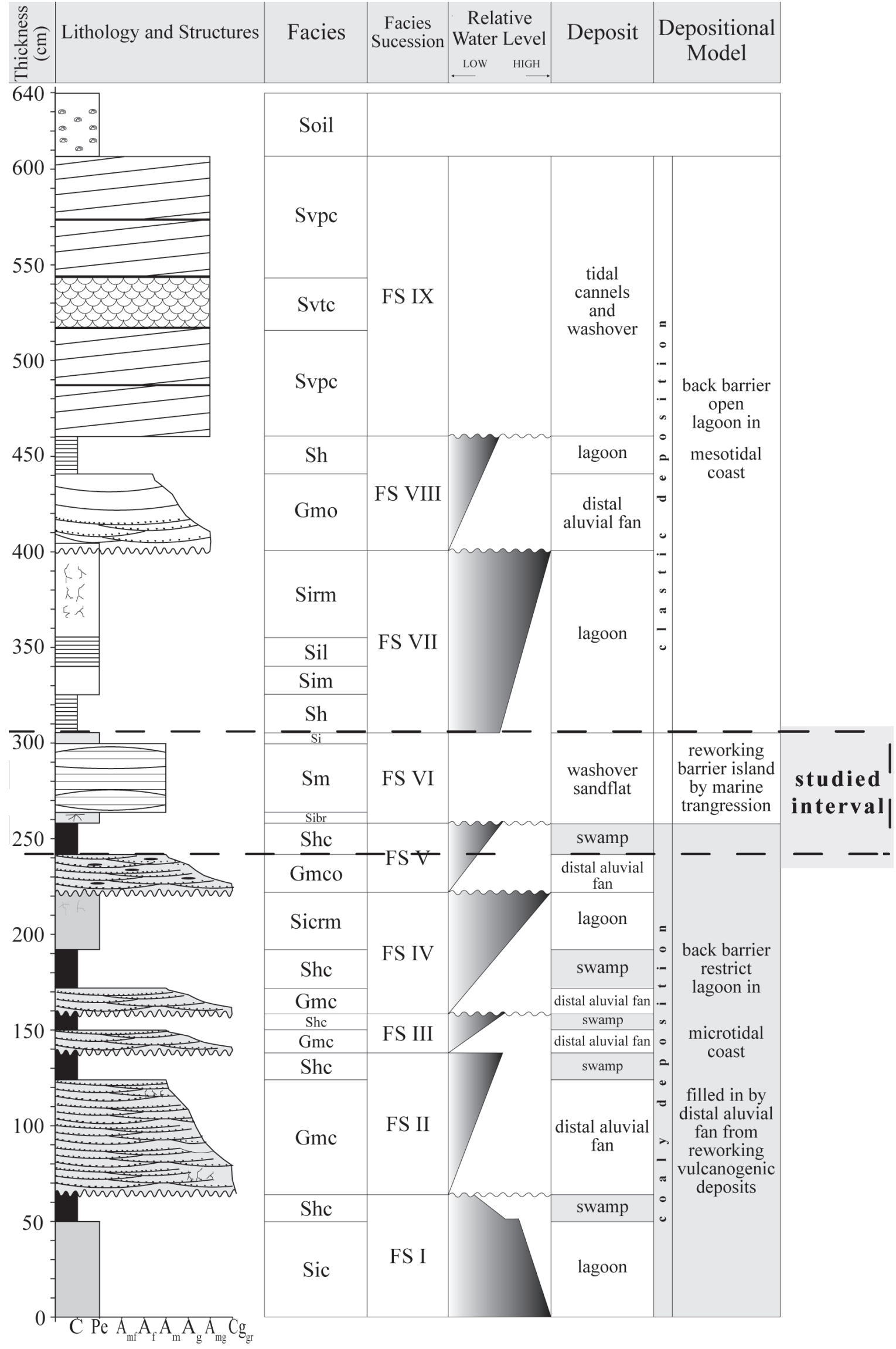

Figure 3. Columnar section of the Quitéria Outcrop. Dotted lines indicate the studied interval. Key for facies succession in Table 1. 
The first attempt to establish radiometric data in claybeds characterized as tonsteins in the southern Brazilian coal succession was made by Matos et al. (2001). They used the IDTIMS U-Pb method to date zircons of the Tonstein A, interbedded with the Lower Candiota coal seam The U-Pb age of $267.1 \pm 3.4 \mathrm{Ma}$ confined the interval of deposition to the top of the Kungurian, base of the Roadian, according to the chronostratigraphic framework of Jin et al. (1997). The radiometric data possess problems related to the Permian depositional model and its effect on the palynostratigraphic schemes established for the Paraná Basin, and this dating has been questioned by different authors. U-Pb SHRIMP analysis of zircons from samples of tonstein beds intercalated in the Candiota coal seams furnished an age of 298.5+2.6 Ma (Rocha-Campos et al., 2006). Guerra-Sommer et al. (2008a) performed radiometric analyses in tonsteins of the Candiota Coalfield (IDTIMS U-Pb) and the age of crystallization of the zircons from the Tonstein A was interpreted as $296 \pm 4.2 \mathrm{Ma}$ (Asselian). Radiometric data were also obtained by GuerraSommer et al. (2008b) from the tonstein layer interbedded in the upper coal seam (S) in the Faxinal Coalfield. The zircon age of $285.4 \pm 8.6 \mathrm{Ma}$ (IDTIMS U-Pb) confined its deposition to the Sakmarian. Nevertheless, the zircon mean age of 290.6 $\pm 1.5 \mathrm{Ma}$, obtained by U-Pb SHRIMP zircon dating of tonstein layers interbedded with coal seams from the Candiota and Faxinal coalfields, in the southern Paraná Basin (Brazil), led Guerra-Sommer et al. (2008c) to the conclusion that the formation of the main coal seams occurred during a time interval confined to the Middle Sakmarian. The \pm 2 Ma time interval of deposition supports the hypothesis that this process involved a single depositional event.

The study area comprises the Quitéria outcrop which is located in the vicinity of the southeastern outcrop belt of the Rio Bonito Formation of the Paraná Basin in southern Brazil
(Figure 1B). The nine vertical facies successions (FS; Table 1) identified in the Quiteria Outcrop (Jasper et al., 2006) represent cycles of relative variations of the water level in a lagoon, ranging from markedly water level (FS I) to relatively falling rising water level (FS VI to FS IX). The basal section represents a coastal depositional system associated with a restricted lagoon protected by barrier/island in micro-tide conditions (Leeder, 1999; Reison, 1992). These facies are interbedded with a matrix supported by conglomerates (Figure 3 ) interpreted as distal alluvial fans. Petrographic analyses identified low-weathered glass fragments, represented by vitreous, vesicular and laminar shaped fragments, in a_reddish silt-sandy matrix, indicate the proximity to the source, probably related to close hinterlands.

The clastic overlying yellow-reddish section (identified by FS VI to IX) represents washover facies (FS VI) corresponding to the breakage of the barrier brought about by washover fans. The episodic event recorded by FS VI drove the ingression of sandy material in the flooded lowlands from marine provenance. The ecology of the former environment changed, with the generation of a clastic sandy soil. The definition of the facies and facies succession, previously detailed by Jasper et al. (2006), is synthesized in Table 1, and the columnar section of the outcrop is presented in Figure 3.

\section{COAL-ROOF SHALE TRANSITION}

The transition from a peat-forming to a clastic environment in the Quitéria outcrop is represented by a peculiar peatclastic interface. Coal palynofloras, being mainly hypoauthochtonous, give a good quantitative estimate and certainly a good qualitative view of the coal-forming floras (Figure 4).

\section{Coal IV}

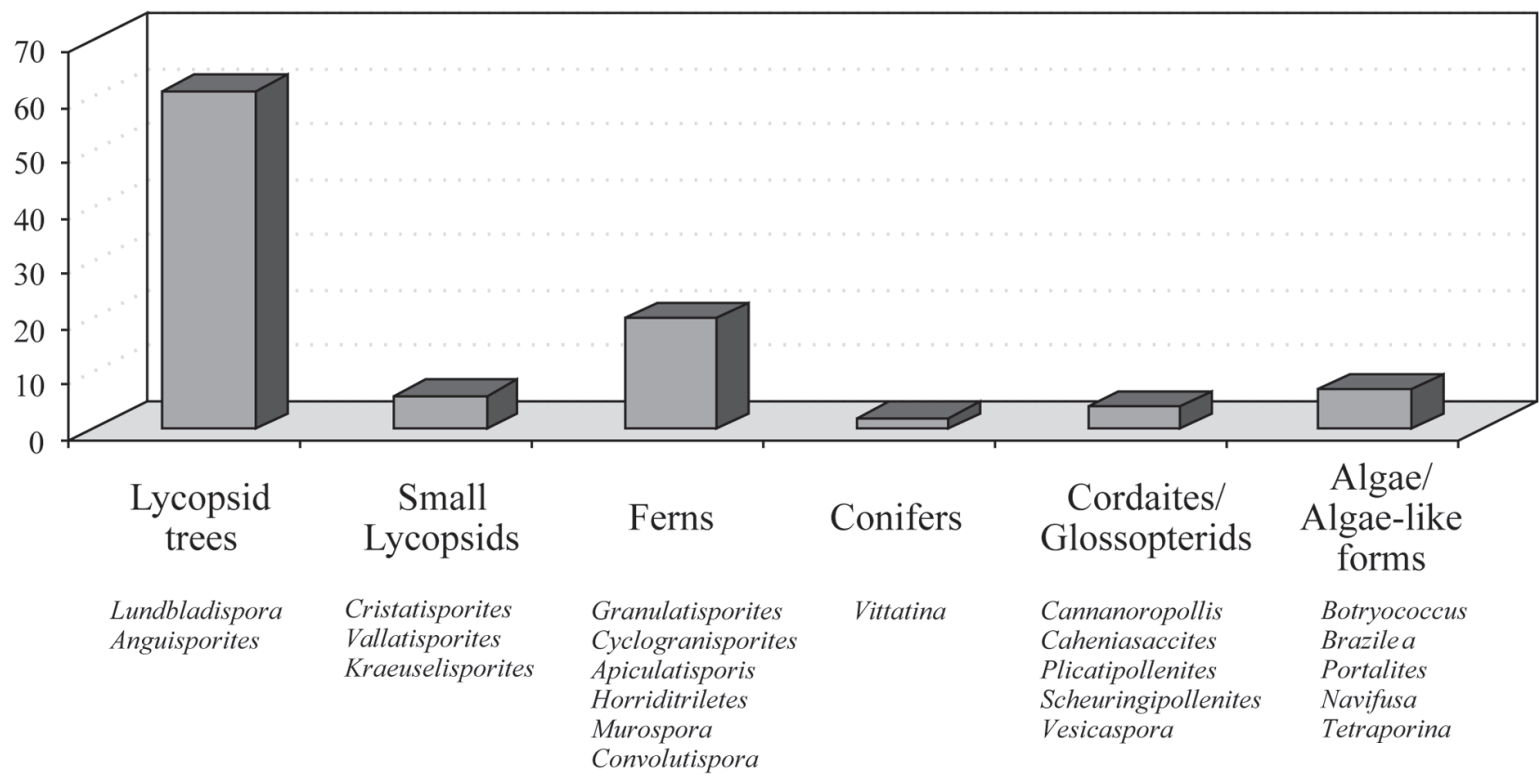

Figure 4. Relative abundance of plant groups represented in the mire based on palynological analysis of the coal/carbonaceous shale level. 

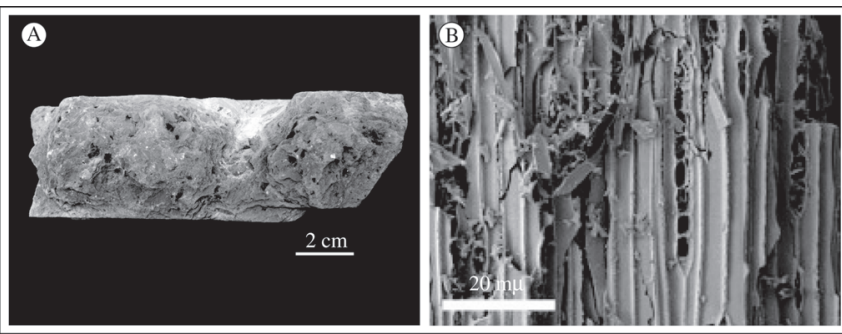

Figure 5. A, dispersed charcoal fragments in the carbonaceous shale; B, SEM microscopic view of a charcoal fragment (photo from Jasper et al., 2008).

The palynofloras identified in carbonaceous shales and coals in Quitéria reflect the regional vegetation of coal_forming plant_communities, transported from nearby areas to the mire developed in a restricted lagoon protected by a barrier island. Some algae-like elements, such as Brazilea, Tetraporina Maculatasporites and Portalites, are commonly found in south Brazilian coal palynofloras together with terrestrial spores and pollen. For Tiwari et al. (1994), these organicwalled microfossils of doubtful origin are good indicators of depositional environments under marine influence. In south Brazilian coal palynofloras, they were linked to freshwater conditions (Marques-Toigo \& Corrêa da Silva, 1984). In relation to the paleoecology of the Botryococcus alga, although it has been traditionally related to fresh to brackish conditions (Batten \& Grenfell, 1996), in some south Brazilian coal palynofloras it has been identified together with Navifusa and Cymatiosphaera (Meyer, 1999; Meyer \& Marques-Toigo, 2000), both belonging to the Acritarch group (Strother, 1996), which indicates transgressive conditions. Richardson \& Rasul (1990) also related these forms to depositional settings with marine influence. On the other hand, Grice et al. (1998), and Versteegh et al. (2004) linked Botryococcus to hypersaline systems. These records allow the inference that these palynomorphs, common in the south Brazilian coals, could tolerate greater salinity conditions. Cazzulo-Klepzig (2002) and Cazzulo-Klepzig et al. (2005) emphasized the

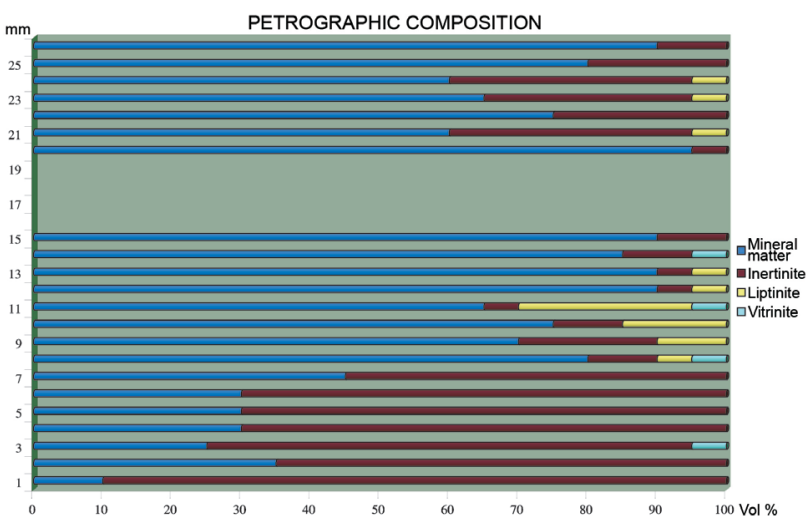

Figure 6. Petrographic composition of sample from the carbonaceous shale showing proportions of mineral matter, inertinite, liptinite and vitrinite in a polished section perpendicular to bedding (see text for details), associated with vitrinite (collotelinite, medium gray). Length of long-axis approximately $200 \mu \mathrm{m}$.

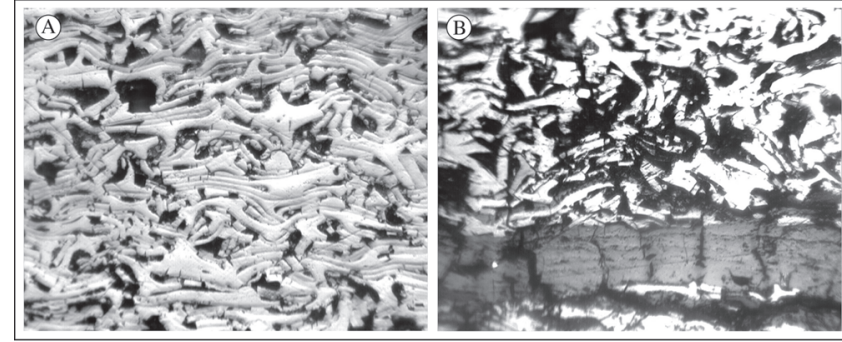

Figure 7. A, enrichment of inertodetrinite in basal section of the sample, showing "bogen" structure typical for fusinite derived organic matter. Length of long-axis approximately $200 \mu \mathrm{m}$. B, inertodetrinite (white).

paleoecological significance of these palynomorphs for peatforming reconstruction, particularly their relation to a gradient from fresh to brackish and up to marine conditions. The authors suggested that they had been carried to the mire by episodic flooding and deposited together with the terrestrial material and fragments of the alga Botryoccocus. Spores derived from pteridophytic vegetation which flourished at the mire edges (herbaceous lycopsids and small ferns) and pollen grains produced by hygrophilous, mesophilous arborescent vegetation inhabiting nearby areas (Cordaites and glossopterids) were also transported to the mire (Remy, 1975). The presence of conifers is reflected by rare striate pollen grains such as Vittatina.

The dominance of the genus Lundbladispora, reflecting the significant presence of arborescent lycopsid trees in the original plant community (Archangelsky \& Césari, 1990; Cazzulo-Klepzig et al., 2005), with a percentage exceeding $60 \%$, are found frequently grouped into tetrads. This indicates their short transport from nearby lowland areas to the mire, considering that the propagules of arborescent lycopsids had a rather limited dispersal range and are less susceptible to transport, particularly when compared with dispersed miospores (Hemsley et al., 1999). The high frequency of

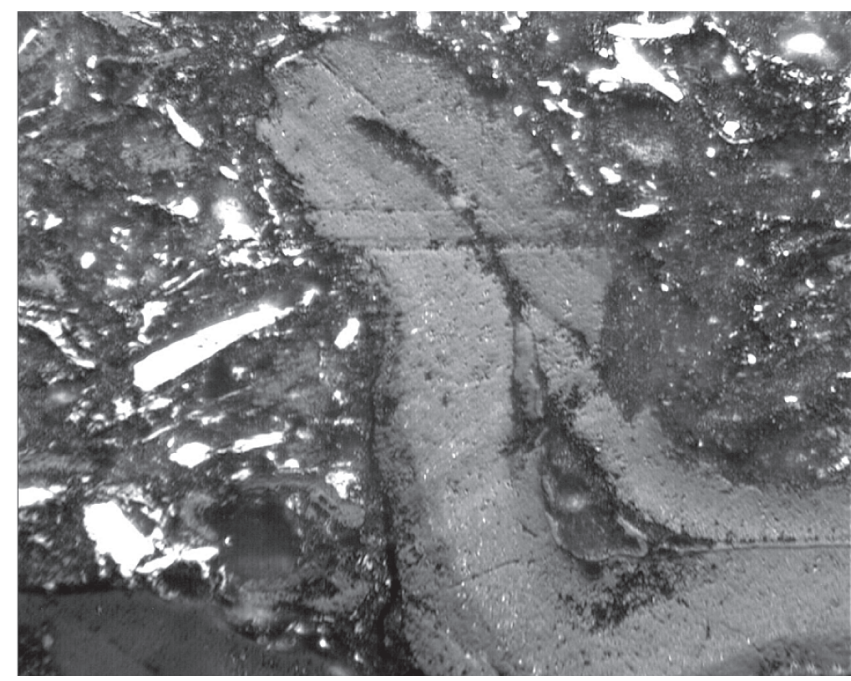

Figure 8. (Mega)-sporinite associated with inertodetrinite (white) and mineral matter (clay minerals and quartz). Length of long-axis approximately $200 \mu \mathrm{m}$. 


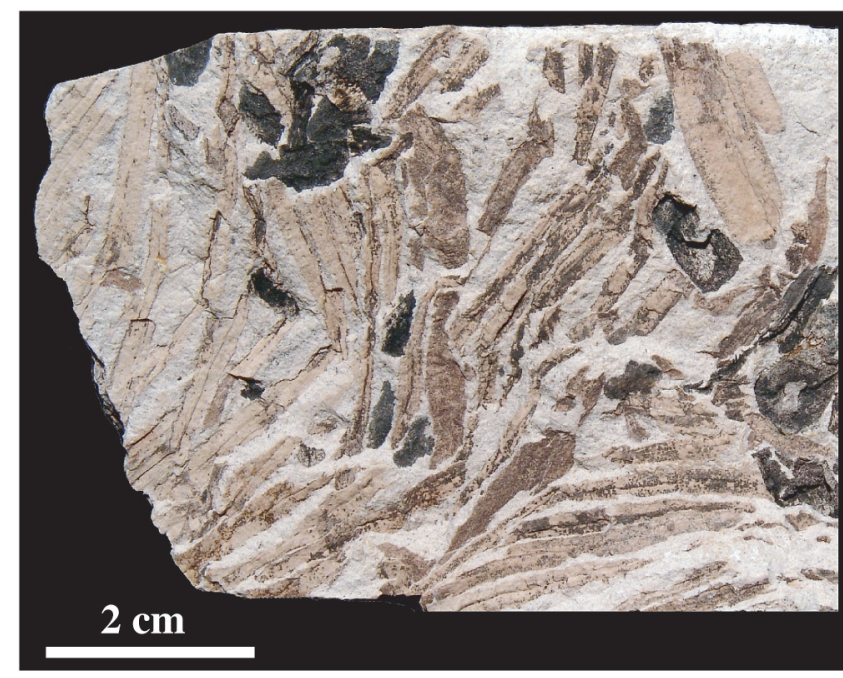

Figure 9. Brasilodendron pedroanum radiating roots and charcoal fragments in paleosol.

masses of lycopsid tetrads has been used for paleoenvironmental interpretation, indicating low energy depositional settings, besides short duration of transport (Tyson, 1995). The presence of megaspores of arborescent lycopsids (Scott \& King, 1981) was detected only under petrographic analyses from carbonaceous shales (Figure 8) and confirms that these plants were an important part of the coal-bearing vegetation.

Charcoal fragments up to $2 \mathrm{~mm}$ in diameter are particularly common as mesofossils in carbonaceous shales (Figure 5A). Jasper et al. (2007) illustrated the anatomical characters of this charcoal association, which can be mainly identified with gymnosperm wood (Figure 5B).

Results from petrographic analysis of continuous carbonaceous shale bands interbedded with the thin coal layer underlying the roof shale flora show at the basal level an enrichment of inertinite macerals, ranging from 55 to 90 vol. \% and mineral matter (Figure 6, interval 1-7). At this level the inertinite is composed almost entirely of inertodetrinite, forming agglomerations parallel to the bedding (Figure 7A).

The center part of the analyzed block (Figure 6, interval 816 ) is characterized by an increase in mineral matter ( 70 to $90 \%$ vol. \%) with only minor contributions of organic matter in the form of macerals of the inertinite, vitrinite and liptinite groups. A representative image for vitrinite (collotelinite) associated with inertinite (inertodetrinite) is shown in Figure $6 \mathrm{~B}$, whereas Figure 8 shows liptinite (mega-sporinite) associated with mineral matter and inertodetrinite.

The top of the analyzed interval (Figure 6, interval 17-21) shows a return to elevated inertinite contents reaching maximum values of $35 \mathrm{vol}$. $\%$.

Enrichment of inertinite macerals in Early Permian coal seams in the Paraná Basin is not an uncommon feature and has been reported in Candiota coals (Holz \& Kalkreuth, 2004; Silva \& Kalkreuth, 2005). In the present study, the inertinite occurs in the form of inertodetrinite, genetically linked to fusinite, with the development of a typical "bogen" structure
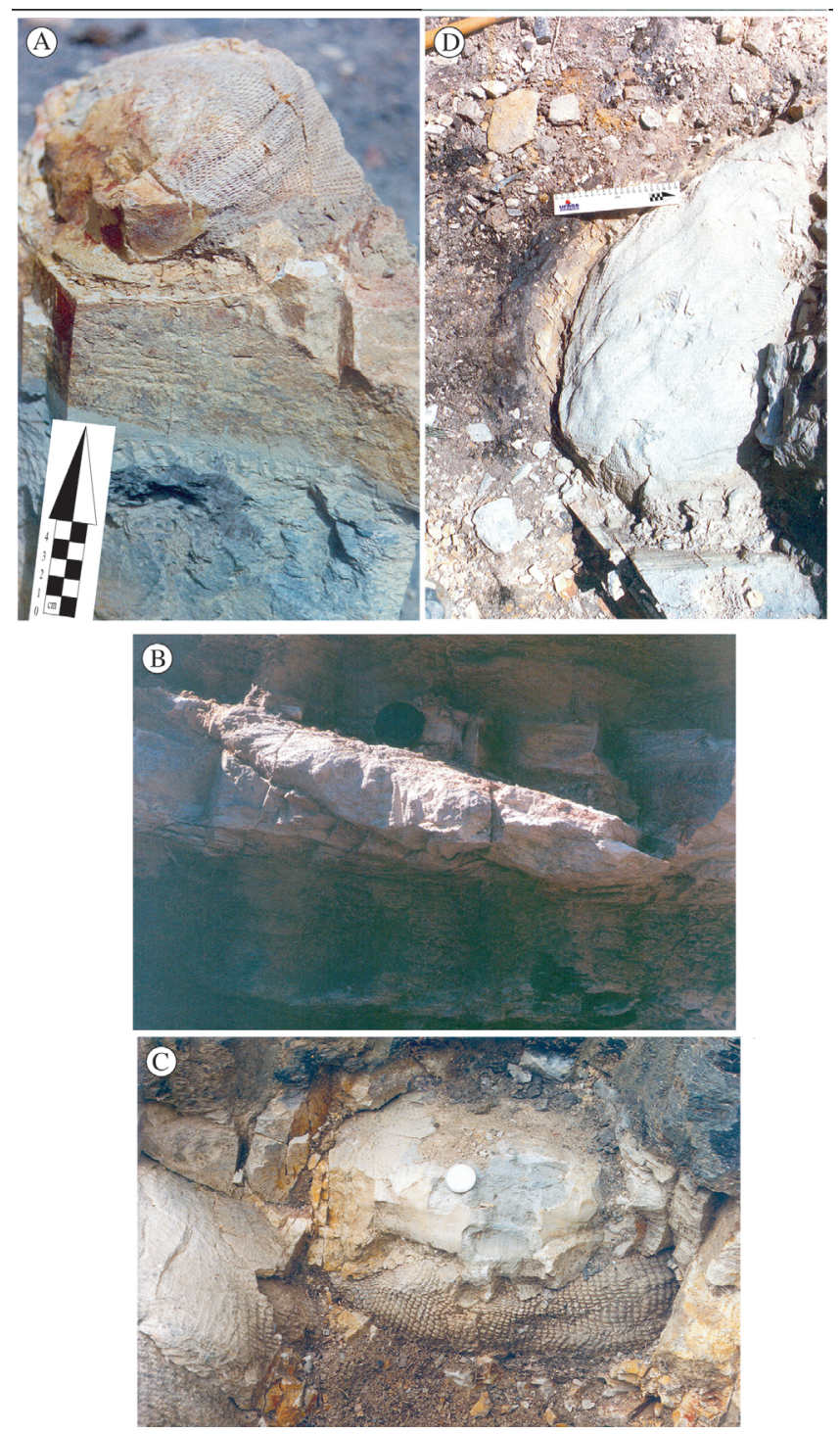

Figure 10. A, C, basal stump of Brasilodendron pedroanum with flared rings, established in a clastic entisoil; B, D. Brasilodendron pedroanum fallen trunk represented by compressed cast; crosscutting of the sediments in angle of $45^{\circ}$.

(Figure 7A). The dominance of detrital inertinite (inertodetrinite) suggests a mechanical breakdown of the precursor material (fusinite) before final deposition in the mire. Fusinite is believed to originate for its major part from forest fires (Scott, 1989; Jones et al., 1993), and the degradation to inertodetrinite most likely occurred during transportation from the site of the forest fire to the final depositional site in the mire (the incompletely burned material being transported by wind and/or water).

The presence of charcoal fragments, combined with the significant content of inertodetrinite in carbonaceous shales and the acceptance of their wildfire origin, indicates that fires occurred in nearby areas and woody charcoalized fragments could have been transported to the peat-generating areas. Significant wildfire activity would be encouraged by periodic dryness.

A very sharp, but otherwise conformable boundary is 


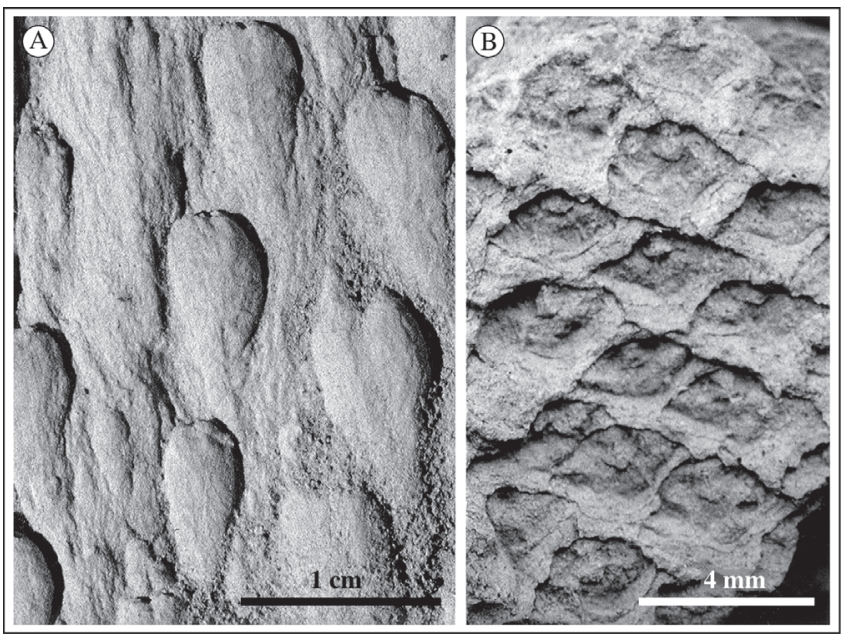

Figure 11. A, fusiform, sigmoid leaf cushion with lepidodendroid phyllotaxis from Brasilodendron pedroanum horizontal compressed stem; B, vertically compressed leaf cushions with lepidodendroid phyllotaxis from Brasilodendron pedroanum basal cast (in situ).

observable at the coal/clastic interface. A mechanism to explain the evolution from peat mire to clastic soil environments was the breakage of the barrier brought about by washover fans, generating the washover plain (Jasper et al., 2006).

The paleosuccession in the roof shale interval was based on statistical analyses (percent cover, diversity index) from the hypoauthochtonous/authochtonous adpressions (Tables 2 and 3). Diameter measurement of the standing lycopsid was also used to infer paleoecological data from the paleoflora (Figure 12). Synthetic description of the plant material from the roof shale facies (Sibr, Sm, Sm with sandy lenses) is presented in Table 4.

The integration of sedimentologic and paleontologic data indicates that the pioneer lycopsid community established on the surface originated from the ingression of sediments on the peat surface but not on the peat itself (Figure 10A). This evidence indicates a span of time between the last phase of coaly swamp plant deposition and the colonization of the paleosoil. The tree bearing paleosoil was very poorly developed, immature, composed of thin siltstone layers, showing alteration represented by charcoal fragments and the presence of 3-5 mm diameter roots (Figure 9). The paleosoil

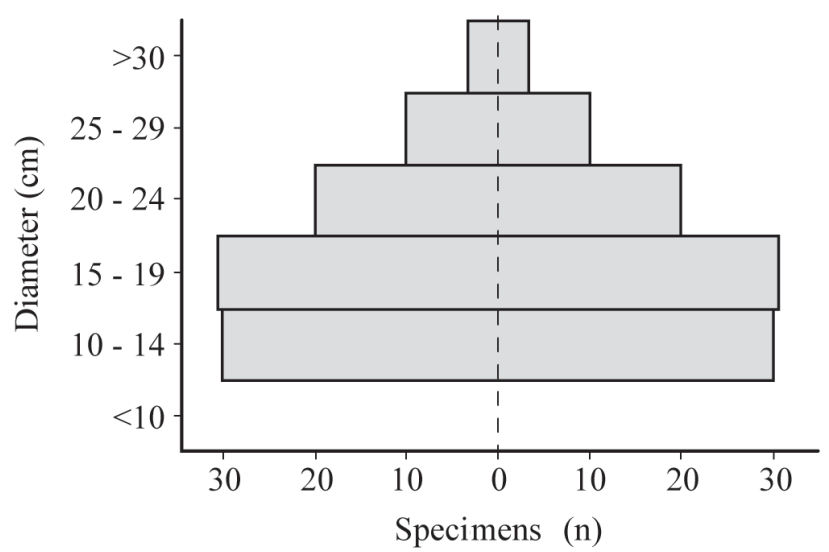

Figure 12. Pyramid of class diameter taken from 30 fossil trunks.
Table 2. Quantitative quadrat analysis in different facies of the roof shale level expressed in terms of percent cover. Zone 1 and 2 refer to Figures $2 \mathrm{~A}$ and $2 \mathrm{~B}$, respectively.

\begin{tabular}{|c|c|c|c|c|}
\hline & & \begin{tabular}{|} 
FACIES \\
Sibr \\
(quadrat:1)
\end{tabular} & $\begin{array}{l}\text { FACIES Sm } \\
\text { (quadrats:2) }\end{array}$ & $\begin{array}{c}\text { FACIES SI } \\
\text { (sandy lenses) } \\
\text { (quadrat:1) }\end{array}$ \\
\hline \multirow{12}{*}{ ¿্̀ } & $\begin{array}{l}\text { Lycophyte ac. root } \\
\text { (Brasilodendron) }\end{array}$ & 48.38 & 25.64 & $\bar{A}$ \\
\hline & $\begin{array}{l}\text { Lycophyte ac. leaf } \\
\text { (Brasilodendron) }\end{array}$ & A & 15.38 & A \\
\hline & $\begin{array}{l}\text { Lycophyte comp. stem } \\
\text { (Brasilodendron) }\end{array}$ & A & 17.94 & A \\
\hline & Lycopodites & A & 2.56 & A \\
\hline & Cordaites leaf & A & A & 26 \\
\hline & Rubidgea leaf & A & 12.82 & A \\
\hline & Coricladus shoot & A & A & A \\
\hline & Botrychiopsis frond & A & 5.12 & A \\
\hline & Rhodeopterid frond & A & A & A \\
\hline & Charcoal & 19.35 & A & A \\
\hline & Total cover area(\%) & 67.73 & 79,46 & 26 \\
\hline & & \begin{tabular}{|c|} 
FACIES \\
Sibr \\
(quadrat:1)
\end{tabular} & $\begin{array}{l}\text { FACIES Sm } \\
\text { (quadrats:2) }\end{array}$ & $\begin{array}{c}\text { FACIES Sm } \\
\text { (sandy lenses) } \\
\text { (quadrat:1) }\end{array}$ \\
\hline \multirow{11}{*}{ 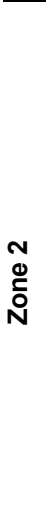 } & $\begin{array}{l}\text { Lycophyte ac. root } \\
\text { (Brasilodendron) }\end{array}$ & 38,5 & A & A \\
\hline & $\begin{array}{l}\text { Lycophyte ac. leaf } \\
\text { (Brasilodendron) }\end{array}$ & A & 13.33 & A \\
\hline & $\begin{array}{l}\text { Lycophyte comp.stem } \\
\text { (Brasilodendron) }\end{array}$ & A & 3.33 & A \\
\hline & Lycopodites & A & 6.67 & A \\
\hline & \multirow{6}{*}{\begin{tabular}{|l|} 
Cordaites leaf \\
Rubidgea leaf \\
Coricladus shoot \\
Botrychiopsis \\
frond \\
Rhodeopterid \\
frond \\
Charcoal \\
\end{tabular}} & A & A & 24 \\
\hline & & A & A & A \\
\hline & & A & 30 & A \\
\hline & & A & 3.33 & $A$ \\
\hline & & A & 20 & A \\
\hline & & 12 & A & A \\
\hline & Total cover area(\%) & 50 & 76.66 & 24 \\
\hline
\end{tabular}

would be classified as entisoil using modern soil taxonomy nomenclature (Brady, 1974). Charcoal could suggest the occurrence of forest fires in lowlands near the study area, contemporaneous to the soil formation.

Burial of basal sandstone cast of lycopsid trees in growth position is evidence of sudden deposition. The basal casts are flared, leafless, decorticated or with poorly preserved scars, sometimes in organic connection to a rooting system that can extend radially up to $16 \mathrm{~cm}$ (Figure 9). These basal casts are frequently tilted (Figure 10A,C), and in some cases are attached to inclined ellipsoid compressed logs up to 30 $\mathrm{cm}$ long (Figure 10B,D). Logs highly compressed

Table 3. Ecological analyses of percent cover data given in Table 2. Zone 1 and 2 refers to Figures $2 A$ and $2 B$, respectively.

\begin{tabular}{|c|c|c|c|}
\hline & FÁCIES & $\begin{array}{l}\text { Species } \\
\text { richness }\end{array}$ & $\begin{array}{l}\text { Simpson } \\
\text { Index (D) }\end{array}$ \\
\hline \multirow{3}{*}{$\begin{array}{l}\bar{\Phi} \\
\stackrel{\Xi}{0} \\
\mathbf{N}\end{array}$} & FACIES Sibr & 2 & 0,376 \\
\hline & FÁCIES Sm & 4 & 0,183 \\
\hline & FACIES Sm (sandy lenses) & 1 & 1 \\
\hline \multirow{3}{*}{$\begin{array}{l}N \\
\stackrel{N}{ } \\
\stackrel{\Xi}{0} \\
N\end{array}$} & FÁCIES Sibr & 1 & 0,556 \\
\hline & FÁCIES Sm & 6 & 0,196 \\
\hline & FÁCIES Sm (sandy lenses) & 1 & 1 \\
\hline
\end{tabular}



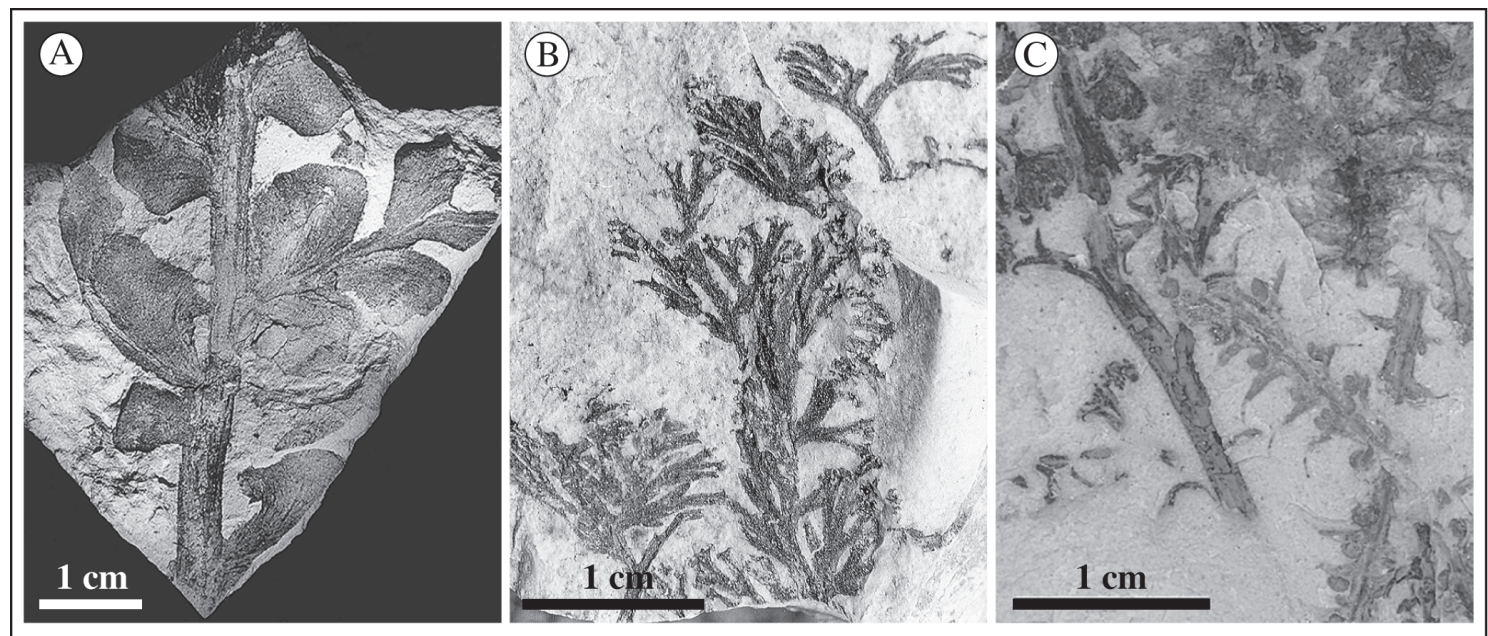

Figure 13. Understorey forms. A, Botrychiopsis valida frond; B; Rhodeopterid frond; C, fertile Lycopodites shoot.

longitudinally ( $1 \mathrm{~cm}$ thickness) are common at this basal level.

The best preserved specimens from both in situ and lycopsid stems highly compressed longitudinally (Figure 11A,B) were attributable by Jasper \& Guerra-Sommer (1998) to Brasilodendron pedroanum Chaloner, Leistikow \& Hill. Dispersed acicular leaves were also attributed to that genus and represent detritus from the lycopsid aerial canopy (Figure 14B2).

The lack of taxonomic diversity and the abundance of Brasilodendron specimens at the site can probably be attributed to restricted paleoenvironmental conditions. Based on available plant fragments, these plants have been tentatively described with reduced crown by Jasper \& GuerraSommer (1998). Diameter measurement taken from the lycopsid casts showed a negatively skewed diameter population, possessing a larger number of plants with smaller-diameter

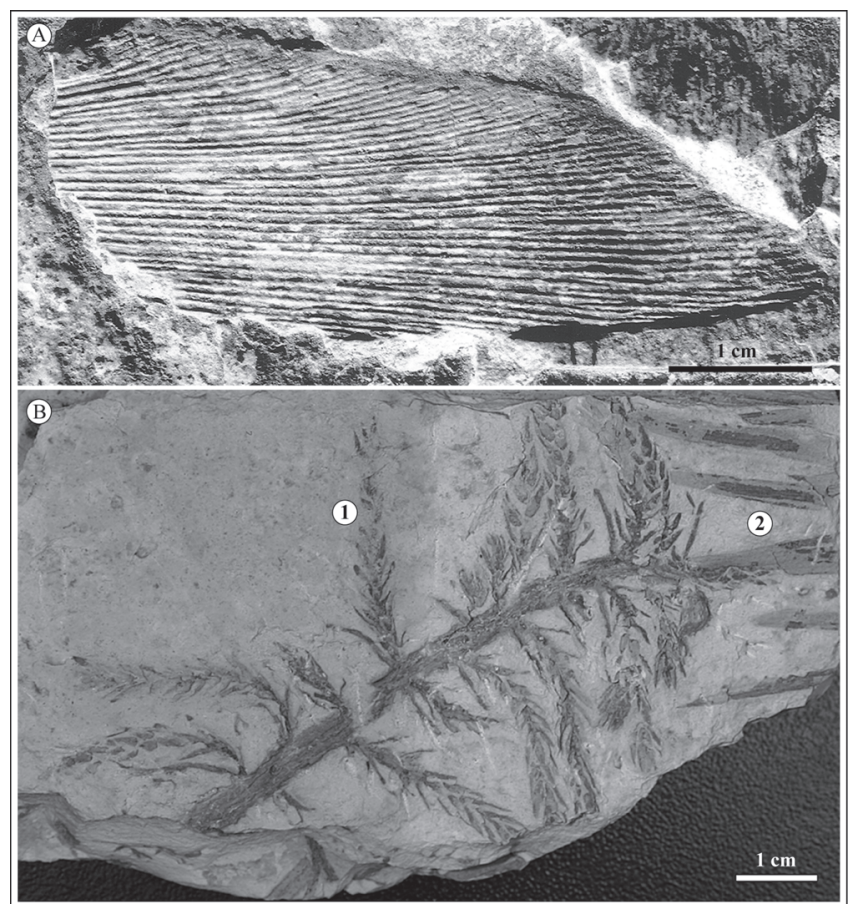

Figure 14. A, Rubidgea; B1, Coricladus shoot; B2, Brasilodendron leaves. trunks (Figure 12). The distribution of class diameter shows a small number of plants with a diameter greater than $30 \mathrm{~cm}$, reflecting an immature plant association, with no gaps between older and younger cohort of trees. These data suggest an uninterrupted colonization, not evidencing paleoenvironmental changes; the environmental disturbance provoked by cyclical washover flows appears to be lethal to almost all the arborescent lycopsids. Detailed statistical analysis of tree spatial distribution was not performed because few data are available. However, quantitative observations indicate a random spatial distribution; consequently, the light competition would not have been a significant factor to determine the self thinning threshold.

Paleoecological data suggest that the arborescent lycopsid assemblage from the Quitéria roof shale has a habit similar to the assemblage described by Falcon-Lang (2004) from an Early Mississippian delta plain setting in New Brunswick, Canada. The trees of the ProtostigmariaLepidodendropsis type are rooted in the interdistributary wetland deposits of prograding wave dominant deltas disturbed by flood.

The state of preservation of delicate structures such as fertile Lycopodites sp. as well as the presence of delicate Botrychiopsis valida Archangelsky \& Arrondo and rhodeopterid fronds (Figure 13) among the in situ basal

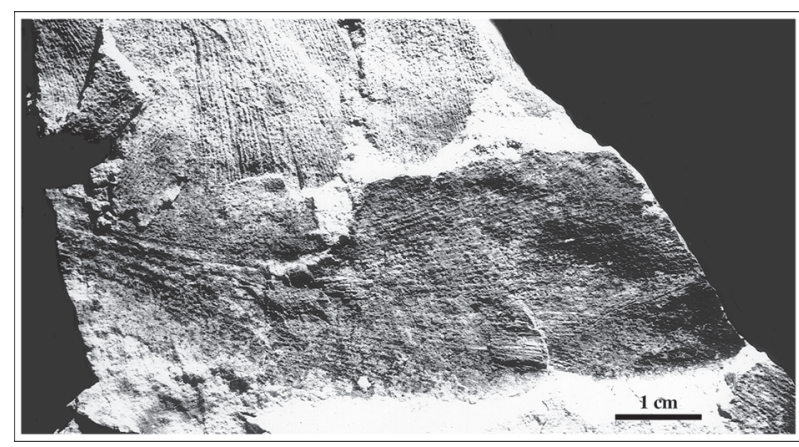

Figure 15. Fragmented impressions of Cordaites leaves scattered, non orientated, in sandy sediment. 

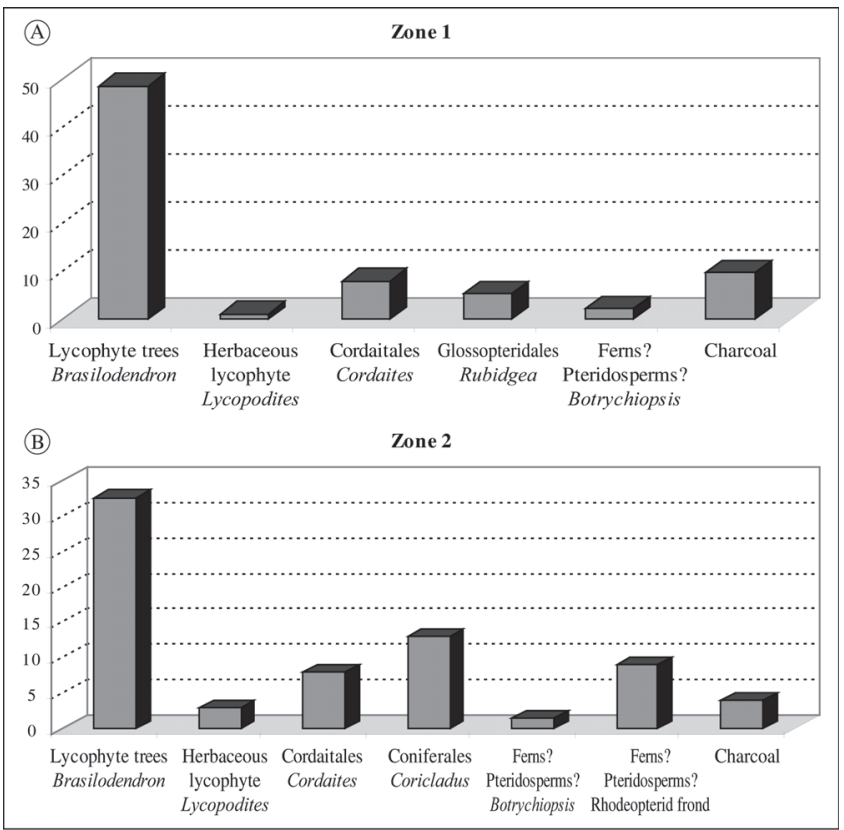

Figure 16. Relative abundance of plant groups represented in the roof shale based in megafloristic analysis. A, zone 1 (see Figure $2 \mathrm{~A}$ ); $\mathrm{B}$, zone 2 (see Figure $2 \mathrm{~B}, \mathrm{C}$ ).

lycopsid casts, suggests that the plant debris corresponds to groundcover forms and barely endured any transport (autochthonous/parautochthonous origin according to: DiMichele \& DeMaris, 1987; DiMichele \& Nelson, 1989; Gastaldo et al., 1990; Gastaldo et al., 1995; Martín-Closas \& Gomez, 2004). These data also suggest the absence of standing water in the area, allowing the growth of groundcover vegetation. Some fluctuation between relatively dry and humid conditions could have occurred, reflecting climatic seasonality.

Large fragments of conifers (Coricladus quiteriensis Jasper, Ricardi-Branco \& Guerra-Sommer, Figure 14B1), frequently with branches and female cones in organic connection, are found in dense associations with groundcover forms. This record suggests an arbustive habit for the plant and a local deposition or minimal transport. This evidence agrees with findings of Palaeozoic fossil plants referring to conifers in southern Brazilian Gondwana (GuerraSommer, 1982) and in Argentina, deposited in extensive plains with meandering rivers (Archangelsky, 1981; Cúneo, 1983; Archangelsky \& Cúneo, 1987). Interbedding with horizons containing marine invertebrates indicates proximity to the sea. Moreover, they are associated with Glossopteridales, ferns, and lycophytes in coal-bearing sequences, suggesting that their habitat was probably mesophilous to hygromesophilous sensu Remy \& Remy (1977). A preferential lowland habitat for the conifers in the southern Brazilian Gondwana was also mentioned by Guerra-Sommer (1982), which suggests their growth within the catchment basin. The phylogenetic implications, reproductive biology and paleoecology of these plants suggest that these conifer types differ from equatorial belt coeval conifers. At the Quitéria roof shale level, the lateral contact between vegetation dominated by conifer shoots (Coricladus quiteriensis and Brasilodendron pedroanum) and assemblages where
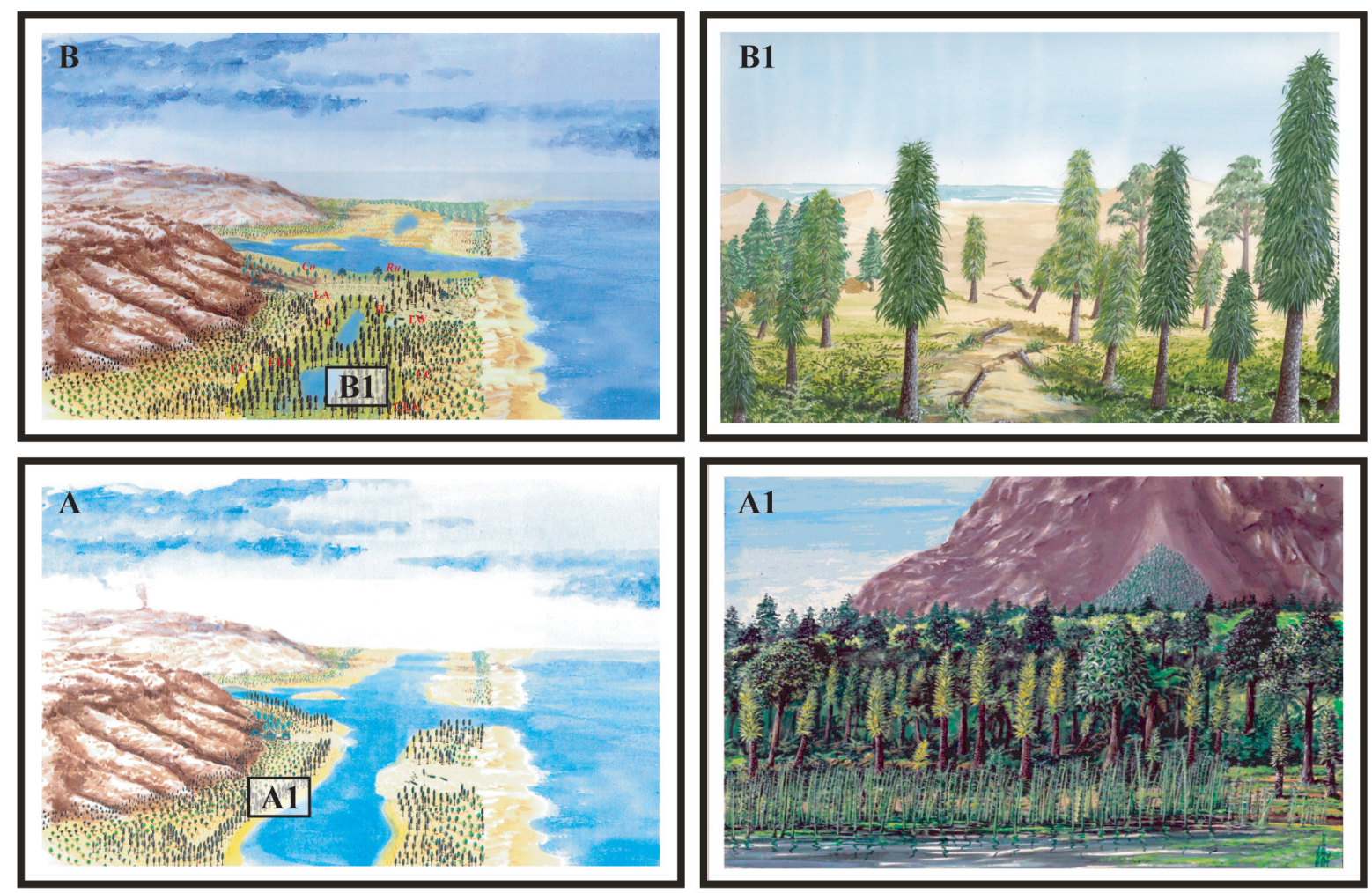

Figure 17. Reconstruction of a coastal ecosystem dominated by washover fans. A, palaeoecological reconstruction for the coal deposition interval; A1, detail of the peat-forming plant community (Shc facies, see Figure 3); B, palaeoecological reconstruction for the overlying clastic deposition interval; B1, detail of the clastic plant community ( Sibr, Sm facies, see Figure 3). 


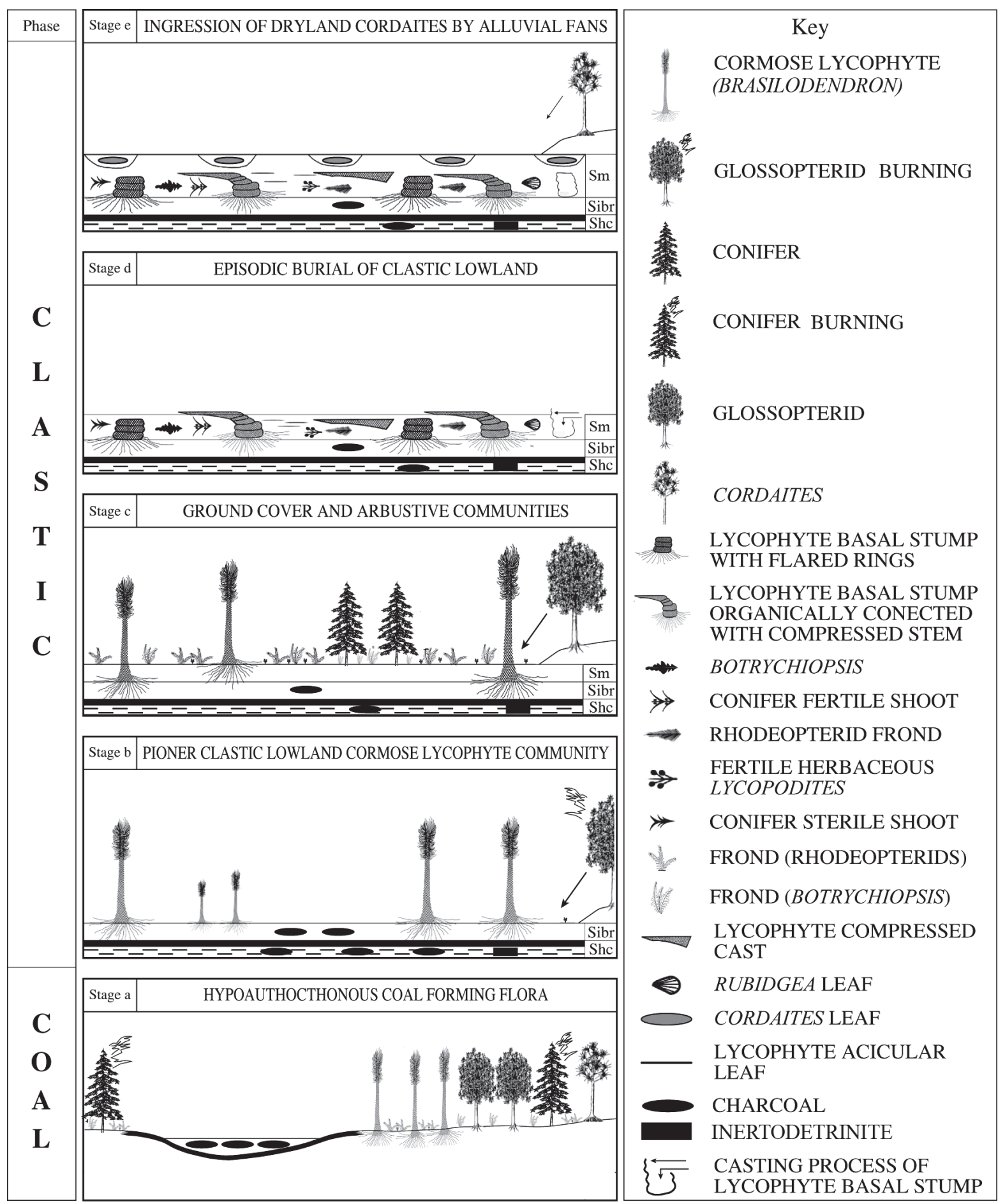

Figure 18. Schematic evolution of the process of colonization, succession and burial of the clastic plant community and its relation to underlying peat-generating floras. Key for facies succession in Table 1.

conifers are absent, indicates that two vegetation types were segregated in a restricted area (Figure 2).

Glossopterids, represented mainly by median parts of leaves (apical and basal parts are rare) of Rubidgea (Figure14A) may indicate their transport from surrounding lands related to a washover flat area. The random distribution of the hypoauthochtonous rubidgeoid isolated leaves throughout the site demonstrate that glossopterids were adapted to the larger coastal depositional system where arborescent lycopsid communities flourished and that they were transported to the site of deposition by episodic flooding.

Fragmented Cordaites leaves, scattered exclusively in extensive lenses of coarse sandstones at the top of the roof shale level (Figure 15) represent a significant paleoecological marker. Cordaites trees constituted a diverse group in coalforming floras in the Euramerican Kingdom. This plant assemblage included mangrove-like plants and understorey 
Table 4. Synthetic description on taxonomy and preservation type of the plant fossil remains in the roof shale level.

\begin{tabular}{|c|c|}
\hline Material & Description \\
\hline $\begin{array}{l}\text { Brasilodendron } \\
\text { pedroanum }\end{array}$ & $\begin{array}{l}\text { Casts of highly longitudinally compressed stems: Fragments with } 0.5-6.0 \mathrm{~cm} \text { in diameter, } \\
4.0-15 \mathrm{~cm} \text { long and } 3.0-20.0 \mathrm{~cm} \text { wide, with fusiform, heliptical or sigmoid leaf cushions (0.3- } \\
0.4 \mathrm{~cm} \text { large and } 0.5-0.9 \mathrm{~cm} \text { long) and lepidodendroid phyllotaxis. Parichnos and ligule not } \\
\text { visible. Detailed description in Jasper \& Guerra-Sommer (1998). }\end{array}$ \\
\hline $\begin{array}{l}\text { Brasilodendron } \\
\text { pedroanum }\end{array}$ & $\begin{array}{l}\text { Casts of stems with elpsoidal diameter, with superficial fusiform, sigmoid leaf cushions (0.3- } \\
0.4 \mathrm{~cm} \text { large and } 0.5-0.9 \mathrm{~cm} \text { long) and lepidodendroid phyllotaxis. Parichnos and ligule not } \\
\text { visible. }\end{array}$ \\
\hline $\begin{array}{l}\text { Brasilodendron } \\
\text { pedroanum }\end{array}$ & $\begin{array}{l}\text { Basal cilindric casts with } 1.5-25.0 \mathrm{~cm} \text { long and } 9.0-20.0 \mathrm{~cm} \text { in diameter with basal flared } \\
\text { rings. Basal portions with elongated acicular roots }(0.4 \mathrm{~cm} \text { in diameter). At the top rhombic- } \\
\text { helicoidal leaf cushions }(0.3-0.4 \mathrm{~cm} \text { large and } 0.5-0.7 \mathrm{~cm} \text { long) and lepidodendroid } \\
\text { phyllotaxis. Parichnos and ligule not visible. Detailed description in Jasper \& Guerra- } \\
\text { Sommer (1998). }\end{array}$ \\
\hline Lycopodites sp. & $\begin{array}{l}\text { Impression/adpression of shoots with } 0.5-2.3 \mathrm{~cm} \text { long and } 0.4 \mathrm{~cm} \text { wide presenting acicular } \\
\text { leaves }(0.1-0.2 \mathrm{~cm} \text { long) with a spiral and alternate-opposite disposition. Ovoid sporanges } \\
\text { with }(0.2 \text { long and } 0.1 \mathrm{~cm} \text { wide) adpressed at the basal portion of leaves. }\end{array}$ \\
\hline $\begin{array}{l}\text { Botrychiopsis } \\
\text { valida }\end{array}$ & $\begin{array}{l}\text { Impression of frond fragments }(3.8-9.0 \mathrm{~cm} \text { long and } 0.6-7.9 \text { wide) with a robust main rachis } \\
\text { presenting strong longitudinal nervures. Pines rhomboidal-ovoid to rhomboidal-elongated } \\
(0.8-1.8 \mathrm{~cm} \text { long and } 1.3-1.8 \mathrm{~cm} \text { wide) presenting an open venation derived from the rachis } \\
\text { nervures. Detailed description in Jasper et al. (2003). }\end{array}$ \\
\hline $\begin{array}{l}\text { Rhodeopterid } \\
\text { fronds }\end{array}$ & $\begin{array}{l}\text { Delicately dichotomized fronds }(0.5-5.6 \mathrm{~cm} \text { long and } 0.1-0.2 \mathrm{~cm} \text { wide), presenting a parallel } \\
\text { venation. }\end{array}$ \\
\hline $\begin{array}{l}\text { Coricladus } \\
\text { quiteriensis }\end{array}$ & $\begin{array}{l}\text { Ramified vegetative and fertile branches }(6.1-84.3 \mathrm{~cm} \text { long and } 2.4-6.5 \mathrm{~cm} \text { wide), leafless, } \\
\text { other with homomorphic, acicular and sessil leaves }(0.1-0.5 \mathrm{~cm} \text { long and } 0.1 \mathrm{~cm} \text { wide) with } \\
\text { parallel venation. Ovuliferous scales and seeds adpressed to the main axis. Detailed } \\
\text { description by Jasper et al. (2005). }\end{array}$ \\
\hline Rubidgea sp. & $\begin{array}{l}\text { Medial and rounded apical parts of leaves with parallel veination at the central part of the } \\
\text { lamina, recurvered in the peripherical region, rarely dichotomized at the base. }\end{array}$ \\
\hline Cordaites sp. & $\begin{array}{l}\text { Strap-like leaves (5.2-23.0 } \mathrm{cm} \text { long and 3.8-4.1 } \mathrm{cm} \text { wide), with pronounced parallel } \\
\text { venation, not anastomosed. }\end{array}$ \\
\hline Charcoal & Fusinised gimnospermic wood fragments. \\
\hline
\end{tabular}

shrubs, inhabiting well-drained clastic lowlands but also peatforming swamps (Cridland, 1964; Scott, 1977; Raymond \& Phillips, 1983; Rothwell \& Warner, 1984; Costanza, 1985; Raymond, 1988; Taylor \& Taylor, 1993). Its presence in the top of the Quitéria roof shale was interpreted as the ingression of remains of a parauthochtonous seasonal dryland flora within the depositional system. It is not possible to determine with certainty their site of growth due to the fact that they were transported to the site probably by distal washover fans; nevertheless, their habit could be similar to those forms described by Falcon-Lang (2005) for the Pennsylvanian of Canada. Cordaites remains were preserved at that site in microtidal deposits inferred to have been formed in the close proximity of the sea coast, on the shore_of a brackish epicontinental sea.

The low diversity index of taxa (Table 2) observed in the hypoauthochtonous plant assemblage can be even overestimated because each organic taxon was counted as an individual species. In the overall association, only seven biological species were identified (Table 3 ). These parameters have been interpreted as indicative of communities that exist in a seasonally stressed biome (Pryor \& Gastaldo, 2000).

Comparing the quantitative results obtained from roof shale floras expressed in Figure 16 to those based on data from the underlying coal palynofloras (Figure 4), it is clear that the roof shale community reflects in part the plant community growing in the lowland areas and constitutes the peat-forming plant communities. The dominance of arborescent lycophytes among other plants is remarkable. The distribution of other plant groups could have been controlled by different factors such as soil composition, differential stage of maturity presented by the vegetation and also by probable taphonomic bias.

The evolution of the_local paleoecological environment at both the coaly (Shc facies, Figure 3 ) and the clastic (Sibr, Sm facies, Figure 3) intervals is represented in Figure 17. A framework representing the process of colonization, succession and burial of the clastic plant community and its relation to the underlying peat-generating floras is presented in Figure 18.

\section{CONCLUSIONS}

The present study, based on the transition from a peatforming to a clastic environment in the Quiteria outcrop, allowed the conclusions presented below.

The deposition process was controlled by paleonvironmental changes due to the break of the barrier brought about by washover fans, generating a washover plain. The burial of the mire by washover fans terminated the hypoauthochtonous peat accumulation. The lowland mineral substrate habitats that were deposited in the same site, after the cessation of peat formation generated an immature sandy soil, colonized by a pioneer arborescent lycopsid community, 
composed by an assemblage of Brasilodedron pedroanum type of plants. After the stabilization of the entisoil, arborecent lycopsids were joined by lowland conifers (Coricladus quiteriensis) and other understorey taxa such as Botrychiopsis plantiana, Lycopodites sp. and other groundcover forms adapted to life in lowland, mineral-poor sandy soils. The presence of hypoauthochtonous glossopterids (Rubidgea) demonstrates that these plants were also adapted to coastal depositional systems. Cordaites trees were also present in this marine-influenced coastal habitat, but adapted to a nearly different habitat.

The immature nature of the arborescent lycopsids from the roof shale resulted from environmental disturbance that killed the whole plant association, preventing the establishment of climax vegetation. The most important cause of disturbance was cyclical washover flows, which appear to have been lethal to the understorey vegetation and also to the arborescent lycopsids.

The development of the authochtonous roof shale flora was not linked to severe changes in relation to the hypoauthochtonous coal-generating floras, but rather to changes in paleosoil characteristics; it can be assumed, consequently, that some surviving members of the plant communities originating the hypoauthochtonous peat mire may also have played a role in the new clastic community, but with a different dominance pattern. The soil surface was free of standing water, at least in some periods; this evidence is consistent with a seasonally stressed biome and reconciles the accumulation of the studied sequence with some periodic dryness of the environment, suggesting seasonality during the Early Permian of the southern Paraná Basin.

The wildfires had important impacts on the type of organic matter accumulated in the coastal mire systems, as evidenced by the presence of mesoscopic charcoal fragments and charcoal-like inertinite macerals (fusinite, inertodetrinite).

\section{ACKNOWLEDGMENTS}

This study was supported by personal and study grants from the Conselho Nacional de Desenvolvimento Científico e Tecnológico. The authors are grateful for the helpful comments from two anonymous referees.

\section{REFERENCES}

Alves, R.G. \& Ade, M.V.B. 1996. Sequence stratigraphy and coal petrography applied to the Candiota coalfield, Rio Grande do Sul, Brazil: a depositional model. International Journal of Coal Geology, 30:231-248.

Archangelsky, S. 1981. Estudios fitopaleoecológicos en el Paleozoico Superior del Oeste de Chubut, Argentina. In: CONGRESSO LATINOAMERICANO DE PALEONTOLOGIA, 2, 1981. Anais, Porto Alegre, p. 141-156.

Archangelsky, S. \& Césari, S. 1990. Ultraestructura de la exina en ejemplares carboníferos de Lundbladispora (Licofita). Ameghiniana, 27(1/2):131-139.

Archangeslky, S. \& Cúneo, R. 1987. Ferugliocladaceae, a new conifer family from the Permian of Gondwana. Review of Palaeobotany and Palynology, 51:3-30.

Balme, B.E. 1995. Fossil in situ spores and pollen grains: an annotated catalogue. Review of Palaeobotany and Palynology, 36:95-163.

Batten, D.J. \& Grenfell, H.R. 1996. Green and blue-green algae Botryoccocus. In: J. Jansonius \& D.C. McGregor (eds.) Palynology: Principles and Applications, American Association of Stratigraphic Palynologists Foundation, p. 205-214.

Bustin, R.M.; Cameron, A.R.; Grieve, D.A. \& Kalkreuth, W.D. 1989. Coal petrology - Its Principles, Methods and Applications. Saint John, Geological Association of Canada, 278 p. (Short Course Notes).

Brady, N.C. 1974. Nature and properties of soils. New York, Mc Millan, $639 \mathrm{p}$.

Berner, R.A. 2006. GEOCARBSULF: A combined model for Phanerozoic atmospheric $\mathrm{O}_{2}$ and $\mathrm{CO}_{2}$. Geochimica et Cosmochimica Acta, 70:5653-5664.

Cazzulo-Klepzig, M. 2001. Significado paleoecológico de alguns palinomorfos ocorrentes nos carvões permianos do Rio Grande do Sul, sul do Brasil. Pesquisas, 25(2):59-65.

Cazzulo-Klepzig, M. 2002. Palinologia aplicada à reconstituição das unidades de paisagem e dinâmica das turfeiras formadoras dos carvões permianos do Rio Grande do Sul, Brasil. Programa de Pós-graduação em Geociências, Universidade Federal do Rio Grande do Sul, Doctoral Dissertation, 300 p.

Cazzulo-Klepzig, M.; Menegat, R. \& Guerra-Sommer, M. 2005. Palynology and paleobotany in the reconstruction of landscape units from the Candiota Coalfield, Permian of Paraná Basin, Brazil. Revista Brasileira de Paleontologia, 8(1):83-98.

Costanza, S.H. 1985. Pennsylvanioxylon of Middle and Upper Pennsylvanian coals from the Illinois Basin and its comparison with Mesoxylon. Palaeontographica B, 197:81-121.

Cridland, A.A. 1964. Amyelon in American coal balls. Palaeontology, 7:189-209.

Cúneo, R. 1983. Paleoecología de las microsecuencias plantíferas del Grupo Rio Genoa, Pérmico de Chubut, Argentina. Ameghiniana, 20:111-131.

Daemon, R.F. \& Quadros, L.P., 1970. Bioestratigrafia do Neopaleozóico da Bacia do Paraná. In: CONGRESSO BRASILEIRO DE GEOLOGIA, 24, 1970. Anais, Brasília, SBG, p. 359-412.

DiMichele, W.A. \& DeMaris, P.J. 1987. Structure and dynamics of a Pennsylvanian-age Lepidodendron forest: colonizers of a disturbed swamp habitat in the Herrin (No. 6) Coal of Illinois. Palaios, 2:146-157.

DiMichele, W.A. \& Nelson, W.J. 1989. Stratigraphic inter-regional changes in Pennsylvanian coal-swamp vegetation environmental inferences. International Journal of Coal Geology, 5:43-109.

Falcon-Lang, H.J. 2004. Early Mississippian lycopsid forests in a delta-plain setting in Norton, near Sussex, New Brunswick, Canada. Journal of the Geological Society, 161:969-981.

Falcon-Lang, H.J. 2005. Small cordaitalean trees in a marine influenced coastal habitat in the Pennsylvanian Joggins Formation, Nova Scotia. Journal of Geological Society, 162:485500.

Gastaldo, R.A.; Demko, T.M. \& Liu. Y. 1990. Carboniferous coastal environments and paleocommunities of the Mary Lee coal zone, Marion and Walker Counties, Alabama. In: ANNUAL MEETING SOUTHEASTERN SECTION OF THE GEOLOGICAL SOCIETY OF AMERICA, 39, 1990. A Guidebook for Field Trip VI, Tuscaloosa, Geological Survey of Alabama, p. 1-139. 
Gastaldo, R.A.; DiMichele, W.A. \& Pfefferkorn, H.W. 1995. Taphonomic and sedimentological characterization of roof shale floras. Geological Society of America Memoir, 185:341-352.

Guerra-Sommer, M. 1982. Coníferas em associações higro-mesófilas no Gondwana brasileiro. In: CONGRESSO BRASILEIRO DE GEOLOGIA, 32, 1982. Anais, Salvador, SBG, 4:1246-1251.

Guerra-Sommer, M. 1988. Padrões epidérmicos da Flora Glossopteris na Jazida do Faxinal (Formação Rio Bonito, Kunguriano, RS): implicações taxonômicas, bioestratigráficas e paleogeográficas. Programa de Pós-graduação em Geociências, Universidade Federal do Rio Grande do Sul, Doctoral Dissertation, 716 p.

Guerra-Sommer, M.; Cazzulo-Klepzig, M.; Formoso, M.L.L.; Menegat, R. \& Mendonça Filho, J.G. 2008a. U-Pb dating of the tonstein layer from a coal succession of the southern Paraná Basin, Brazil: A new geochronological approach. Gondwana Research (in press).

Guerra-Sommer, M.; Cazzulo-Klepzig, M.; Menegat, R.; Formoso, M.L.L.; Basei, M.A S.; Barboza, E.G. \& Simas, M.W. 2008 b. Geochronological data from the Faxinal coal succession, southern Paraná Basin, Brazil: A preliminary approach combining radiometric $\mathrm{U}-\mathrm{Pb}$ dating and palynostratigraphy. Journal of South American Earth Sciences, 25:246-256.

Guerra-Sommer, M.; Cazzulo-Klepzig, M.; Santos, J. O. S.; Hartmann, L. A.; Ketzer, J. M.M. \& Formoso, M.L.L. 2008c. Radiometric age determination of tonsteins and stratigraphic constrains for the Lower Permian coal succession in southern Paraná Basin, Brazil. International Journal of Coal Geology, 74:13-27.

Hemsley, A.R.; Scott, A.C. \& Collinson, M.E. 1999. The architecture and functional biology of freely dispersed megaspores. In: M.H. Kurmann \& A.R. Hemsley (eds.) The Evolution of Plant Architecture. Royal Botanic Gardens, p. 253-277.

Holz, M. 1998. The Eo-Permian coal seams of the Paraná Basin in southernmost Brazil: An analysis of the depositional conditions using sequence stratigraphy concepts. International Journal of Coal Geology, 36:148-163.

Holz, M. \& Kalkreuth, W. 2004. Sequence stratigraphy and coal petrology applied to the Early Permian coal-bearing Rio Bonito Formation, Paraná Basin, Brazil. In: J.C. Pashin \& R.A. Gastaldo. (eds.) Sequence stratigraphy, paleoclimate and tectonics of coal-bearing strata, AAPG Studies in Geology, 51:147-167.

Holz, M.; Kalkreuth, W. \& Banerjee, A. 2002. Sequence stratigraphy of paralic coal-bearing strata: an overview. International Journal of Coal Geology, 48:147-179.

Hughes, R.G. 1986. Theories and models of species abundance. American Naturalist, 128:879-899.

ICCP. 1963. International Handbook of Coal Petrography. $2^{\mathrm{a}}$. ed. International Committee of Organic and Coal Petrology, Paris.

ICCP. 1998. The new vitrinite classification (ICCP System 1994). International Committee for Coal and Organic Petrology, 77:349-358.

ICCP. 2001. The new inertinite classification (ICCP System 1994). International Committee for Coal and Organic Coal Petrology, 80:459-471.

Jasper, A.; Branco, F. R. \& Guerra-Sommer, M. 2005. Coricladus quiteriensis gen. \& sp. nov., a new conifer in Southern Brazil Gondwana (Lower Permian, Paraná Basin). Anais da Academia Brasileira de Ciências, 77(1):157-168.

Jasper, A. \& Guerra-Sommer, M. 1998. Licófitas cormofíticas arborescentes do afloramento Quitéria, Formação Rio Bonito
(Bacia do Paraná), RS. Pesquisas, 25(1):43-60.

Jasper, A. \& Guerra-Sommer, M. 1999. Licófitas arborescentes in situ como elementos importantes na definição de modelos deposicionais (Formação Rio Bonito, Bacia do Paraná, Brasil). Pesquisas, 26:49-58.

Jasper, André; Guerra-Sommer, M.; Cazzulo-Klepzig, M. \& Menegat, R. 2003. The Botrychiopsis genus and its biostratigraphic implications in Southern Paraná Basin. Anais da Academia Brasileira de Ciências, 75(4):513-535.

Jasper, A.; Guerra-Sommer, M.; Uhl, D.; Salvi, J.; Kauffmann, M.; Osterkamp, I.C. \& Gonçalves, C.V. 2007. A ocorrência de incêndios vegetacionais durante o Paleozóico Superior da Bacia do Paraná. In: I.S. Carvalho et al. (eds.) Paleontologia: Cenários de Vida, Interciência, 1:15-23.

Jasper, A.; Menegat, R.; Guerra-Sommer, M.; Cazzulo-Klepzig, M. \& Souza P.A. 2006. Depositional cyclicity and paleoecological variability in an outcrop of Rio Bonito Formation, Early Permian, Paraná Basin, Rio Grande do Sul, Brazil. Journal of South American Earth Sciences, 21:276-293.

Jin,Y.G.; Wordlaw, B.R.; Glenister, B.F. \& Kotlyor, G.V. 1997. Permian chronostratigraphic sub-divisions. Episodes, 20:1020.

Jones, T.; Scott, A. \& Mattey, D. 1993. Investigations of "fusain transition fossils" from the Lower Carboniferous: comparison with modern partially charred wood. International Journal of Coal Geology, 22:37-59.

Leeder, M. 1999. Sedimentology and Sedimentary Basins: from Turbulence to Tectonics. London, Blackwell Science, 592 p.

Martín-Closas, C. \& Gomez, B. 2004. Taphonomie des plantes et interprétations paléoécologiques: une synthèse. Geobios, 37:6588.

Marques-Toigo, M. 1991. Palynobiostratigraphy of the southern Brazilian Neopaleozoic Gondwana sequence. In: INTERNATIONAL GONDWANA SYMPOSIUM, 7, 1991. Proceedings, São Paulo, SBG/USP, p. 503-515.

Marques-Toigo, M. \& Corrêa da Silva, Z.C. 1984. On the origin of Gondwanic south Brazilian coal measures. Comunicações dos Serviços Geológicos de Portugal, 7:151-160.

Matos, S.L.F.; Yamamoto, J.K.; Riccomini, C.; Hachiro, J. \& Tassinari, C.C.G., 2001. Absolute dating of Permian ash-fall in the Rio Bonito Formation, Paraná Basin, Brazil. Gondwana Research, 4:421-426.

Meyer, K.E.B. 1999. Caracterização palinológica das camadas de carvão da Malha IV na Mina de Candiota, RS, Permiano da Bacia do Paraná. Programa de Pós-graduação em Geociências, Universidade Federal do Rio Grande do Sul, Master Thesis, $112 \mathrm{p}$.

Meyer, K.E.B. \& Marques-Toigo, M. 2000. O significado paleoambiental da microflora dos carvões da Malha IV, Mina de Candiota, RS, Permiano da Bacia do Paraná, Brasil. Revista da Universidade de Guarulhos, Geociências, 5:16-20.

Milani, E.J. 2003. Estratigrafia da bacia do Paraná - algumas considerações metodológicas. In: ENCONTRO SOBRE A ESTRATIGRAFIA DO RIO GRANDE DO SUL: ESCUDO E BACIAS, 1, 2003. Anais, Porto Alegre, IGEO/UFRGS, p. 105110.

Nahuys, J.; Alpern, B. \& Ybert, J.P. 1968. Estudo palinológico e petrográfico de alguns carvões do sul do Brasil. Instituto Tecnológico do Rio Grande do Sul, p. 3-61 (Boletim Técnico 46).

Phipps, D. \& Playford, G. 1984. Laboratory techniques for extraction of palynomorphs from sediments. University of 
Queensland, p. 1-23 (Papers of the Department of Geology 11).

Pryor, J. \& Gastaldo, R.A. 2000. Paleoecological analysis of two Early Pennsylvanian mineral substrate wetlands. Palaios, 15(1):3-13.

Quadros, L.P.; Marques-Toigo, M. \& Cazzulo-Klepzig, M. 1995. Catálogo de esporos e pólens fósseis do Paleozóico. Boletim de Geociências da Petrobrás, 9(1):1-151.

Raymond, P.A. 1988. The palaeoecology of a coal-ball deposit from the Middle Pennsylvanian of Iowa dominated by cordaitalean gymnosperms. Review of Palaeobotany and Palynology, 53:233-250.

Raymond, A. \& Phillips, T.L. 1983. Evidence for an Upper Carboniferous mangrove community. Tasks for Vegetation Science, 8:19-30.

Rees, P.M.; Gibbs, M.T.; Ziegler, A.M.; Kutzbach, J.E. \& Behling, P.J. 1999. Permian climates: evaluating model predictions using global palaeobotanical data. Geology, 27:891-894.

Reinson, G.E. 1992. Transgressive barrier island and estuarine systems. In: R.G. Walker \& N.P. James (eds.) Facies models response to sea level change, Geological Association of Canada, p. 179-194.

Remy, W. 1975. The floral changes at the Carboniferous-Permian boundary in Europe and North America. In: I. C. WHITE MEMORIAL SYMPOSIUM "THE AGE OF THE DUNKARD”, 1, 1975. Proceedings, Richmond, p. 305-343.

Remy, W. \& Remy, R. 1977. Die Floren des Erdaltertunms. Essen, Glückauf, 468 p.

Richardson, J.B. \& Rasul, S.M. 1990. Palynofacies in a Late Silurian regressive sequence in the Welsh Borderland and Wales. Journal of the Geological Society, 147:675-686.

Rocha-Campos, A.C; Basei, M.A.S; Nutman, A.P. \& Santos, P.R. 2006. SHRIMP U-Pb Zircon geochronological calibration of the late Paleozoic Supersequence, Paraná Basin, Brazil. In: SOUTH AMERICAN SYMPOSIUM ON ISOTOPE GEOLOGY, 5, 2006. Short Papers, Punta del Este, Universidad de la República, p. 471-474.
Rothwell, G.W. \& Warner, S. 1984. Cordaixylon dumusum n. sp. (Cordaitales): I. Vegetative structure. Botanical Gazette, 145:275-291.

Scotese, C.R. 2000. Paleomap project. [s.n.t.] Avaliable at: $<$ http:/ /www. scotese.com/mtriascl.htm> Accessed in: Sep.04.07.

Scott, A.C. 1977. A review of the ecology of Carboniferous plant assemblages with new data. Paleontology, 20:447-473.

Scott, A.C. 1989. Observations on the nature and origin of fusain. International Journal of Coal Geology, 12:443-475.

Scott, A.C. \& Glasspool, I.J. 2006. The diversification of Paleozoic fire systems and fluctuations in atmospheric oxygen concentration. Proceedings of National Academy of Sciences, 103:10861-10865.

Scott, A.C. \& King, G.R. 1981. Megaspores and coal facies: an example from the Westphalian A of Leicestershire, England. Review of Paleobotany and Palynology, 34:107-113.

Silva, M.B. \& Kalkreuth, W. 2005. Petrological and geochemical characterization of Candiota coal seams, Brazil - implication for coal facies interpretations and coal rank. International Journal of Coal Geology, 64:217-238.

Strother, P.K. 1996. Acritarchs. In: J. Jansonius \& D.C. McGregor (eds.) Palynology, principles and applications. American Association of Stratigraphic Palynologists Foundation, 1:87106.

Taylor, T.N. \& Taylor, E.L. 1993. The Biology and Evolution of Fossil Plants. New Jersey, Prentice-Hall, 982 p.

Tiwari, R.S.; Tripathi, A. \& Vijaya 1994. Organic-walled microfossils of doubtful origin in the Permian and Triassic sequences of Peninsular India. The Palaeobotanist, 43:1-58.

Tyson, R.V. 1995. Sedimentary Organic Matter-Organic Facies and Palynofacies. London, Chapman and Hall, 615 p.

Versteegh, G.J. \& Blokker, P. 2004. Resistant macromolecules of extinct and fossil microalgae. Phycological Research, 2:235339.

Walker, R.G. \& James, N.P. 1992. Facies models - response to Sea Level Change. Saint John, Geological Association of Canada, $409 \mathrm{p}$.

Received in October, 2006; accepted in March, 2008. 